\title{
Unraveling heterogeneity in the importance of ecosystem services: individual views of smallholders
}

\author{
Alejandra Tauro $^{1}$, Erik Gómez-Baggethun ${ }^{2,3}$, Eduardo García-Frapolli $^{1}$, Elena Lazos Chavero ${ }^{4}$ and Patricia Balvanera $^{1}$
}

\begin{abstract}
Stakeholder groups are not homogeneous across individuals and through time, especially in relation to the importance of ecosystem services. However, the approaches commonly used to characterize the average importance and values of stakeholder groups overlook the heterogeneity in the individual priorities. This heterogeneity is particularly relevant for smallholders, who play a key role in ecosystem management but are more vulnerable to globalization than owners of large plots. We analyzed the priorities differentially assigned to ecosystem services and the reasons associated with the importance attributed to those services by individual cattle ranchers on the Pacific Coast of Mexico. We interviewed 27 cattle ranchers from neighboring rural communities. The services perceived by each rancher were identified from selected regional photographs. These services were then arranged in order of importance by interviewees, who were asked to provide the reasons for their choices. We used multivariate methods to examine the relationship between priorities for services and the livelihood of the individual. Interpretative qualitative methods elicited the reasons associated with the relative importance of the prioritized services. We identified 54 different services. Overall, individuals prioritized provisioning services directly related to their ranching activity. Individuals with the highest level of education and greatest diversity of productive activities (e.g., farmer, mason, merchant) also prioritized cultural services associated with ecotourism potential. The reasons associated with the importance attributed to the prioritized services varied widely among individuals. The list of ecosystem services perceived was context-specific, strongly influenced by the salient characteristics of the ecosystem and of the ranching way of life. A generational change in livelihoods has affected priorities. The reasons behind the importance of the prioritized services were diverse among individuals. By revealing the heterogeneity among individuals, we emphasize the need to make flexible policies that integrate diverse values and contexts to accomplish smallholder inclusivity.
\end{abstract}

Key Words: cattle ranchers; family farm; Mexico; photo interviewing; tropical dry forest; well-being

\section{INTRODUCTION}

The heterogeneity within stakeholder groups in relation to the importance of ecosystem services has seldom been explored. However, we know that stakeholder groups are not homogeneous across individuals and through time (Daw et al. 2011, Wieland et al. 2016). The individual experiences of daily life, individual opportunities and interests, and individual interactions with social-ecological systems (Long 2001, Lazos-Chavero et al. 2016) lead to unique and dynamic perspectives on ecosystem services. Yet, the heterogeneity within a particular stakeholder group is rooted in the diverse conceptualizations of ecosystems, and the recognition of this diversity of values is increasingly being identified as fundamental to the building of sustainability (Pascual et al. 2017). The work of the Intergovernmental SciencePolicy Platform on Biodiversity and Ecosystem Services (IPBES) and the Ecosystem Services Partnership has emphasized the need to clarify how different people conceptualize benefits from nature so that the heterogeneity of these understandings is better communicated. This could contribute toward supporting inclusive decision-making processes and sustainable public policies (Jacobs et al. 2016, Pascual et al. 2017, Lau et al. 2018).

The study of socio-cultural values of ecosystem services is expanding (Castro et al. 2011, Iniesta-Arandia et al. 2014, CampsCalvet et al. 2016), but scientists have overlooked the role of heterogeneity across individuals and through time. Nevertheless, standard procedures are based on the aggregation of individuals to assert group preferences, such as the calculation of means, which ignore the variation within a group. Because variation is ignored, assessment of individual choice is limited, and instead, vague generalizations about group choice are made (Hicks et al. 2015). Management based on the averaged interests of a group of stakeholders can lead to the exclusion of minorities or inconspicuous individuals (Daw et al. 2011, Wieland et al. 2016).

Understanding the heterogeneity of individual preferences for ecosystem services can be deepened through the exploration of their importance (Klain et al. 2014, Asah et al. 2014). Assessing the values of ecosystem services through the lens of their importance allows for the exploration of the meaning attributed to the ecosystem services (Pascual et al. 2017). An assessment of the importance of ecosystem services involves both unraveling a hierarchy or the ranking of priorities (quantitative aspects) and analysis of the narrative that justifies the reasons for such importance (qualitative aspects). While the concept of importance has been explored in the valuation of ecosystem services (Klain et al. 2014, Haida et al. 2016, Arias-Arevalo et al. 2017), more emphasis is needed on the interindividual heterogeneity of such importance (Lau et al. 2018) and on indepth explorations of the reasons associated with the identified priorities (but see Klain et al. 2014, Arias-Arevalo et al. 2017).

\footnotetext{
${ }^{1}$ Instituto de Investigaciones en Ecosistemas y Sustentabilidad, Universidad Nacional Autónoma de México (UNAM), Morelia, Mexico, ${ }^{2}$ Department of International Environment and Development studies/ Noragric, Norwegian University of Life Sciences - NMBU, Ås, Norway, ${ }^{3}$ Norwegian Institute for Nature Research - NINA, Oslo, Norway, ${ }^{4}$ Instituto de Investigaciones Sociales, Universidad Nacional Autónoma de México (UNAM), Cd. Mx., Mexico.
} 
Fig. 1. Location of the ejidos adjoining Biosphere Reserve of Chamela-Cuixmala (BRCh-C) on the Pacific Coast of Jalisco, México, where the fieldwork was undertaken. Source: Pérez-Escobedo 2011.

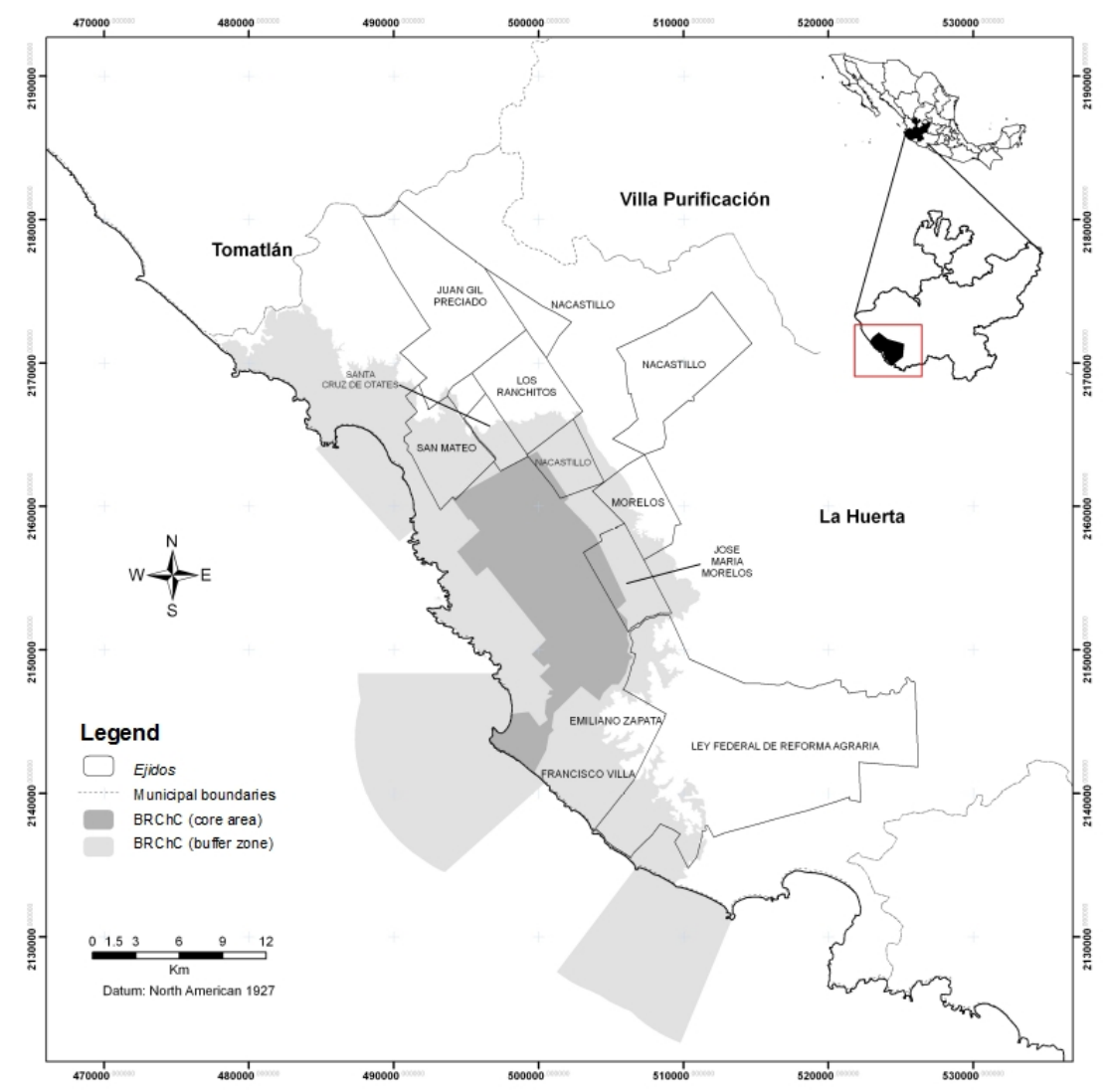

The study of perceptions and priorities, and the reasons for the importance of ecosystem services is vital in the case of smallholder cattle ranchers who manage a large portion of the world's biodiversity and yet are excluded or marginalized from decision-making processes (Apgar 2017). In Latin America, approximately $80 \%$ of agricultural production units are family units (FAO 2014), and of those, 64.5\% are livestock ranchers (Rodríguez et al. 2016). Smallholders contribute significantly to global agriculture (IFAD-UNEP 2013) and food production in Latin America (FAO 2014), but they also face poverty and food insecurity (CELAC 2014). Cattle ranchers have cleared large forest areas to expand grazing lands (Lazos-Chavero 1996, Gerritsen and van der Poegl 2006) in response to the global demand for meat (FAO 2014) and to national public policies (Lazos-Chavero 1996, Chauvet 2001). Hence, it is crucial to understand the viewpoints of smallholder cattle ranchers and to include them in decision-making processes by making the heterogeneity of the importance they attribute to ecosystem services within this group more visible. The integration of heterogeneity into more legitimate, flexible, and inclusive productive and environmental policies will be tightly linked to the environmental governance of the Latin America region.

In this work, we make visible the heterogeneity of the importance of ecosystem services within one group of rural smallholders: the cattle ranchers. We analyze their individual priorities for ecosystem services in order to explore how priorities are linked to livelihoods and to ascertain the reasons for the importance attributed to these services. In particular, we analyze (1) which ecosystem services are perceived and prioritized by cattle ranchers, (2) how socio-demographic factors associated with their livelihood relate to these priorities, and (3) the reasons behind the importance of the prioritized services.

\section{METHODS AND ANALYSIS}

\section{Study site}

We performed this study on the Pacific Coast of Mexico, near the Biosphere Reserve of Chamela-Cuixmala, in the municipality of La Huerta in the state of Jalisco (Fig. 1). This zone forms part of the International Long-Term Ecological Research Network. Information provided by each site of this network will contribute to global understanding of the sustainable management of key ecosystem services (Maass et al. 2016). For more than 40 years, researchers from different disciplines and various institutions in Mexico have selected this area as a site for investigation. This has yielded a high number of ecological and social studies (including more than 1000 theses, papers, books, and book chapters), thereby making this site one of the most studied in tropical America (Perez-Escobedo 2011, Schroeder and Castillo 2013). 
Inhabitants of the lands adjoining the reserve maintain a $70-80 \%$ tropical dry forest cover, with different degrees of conservation, comprising different sized patches (Sánchez-Azofeifa et al. 2009). Average precipitation is $788 \mathrm{~mm}$ per year, with $80 \%$ falling between June and October (García-Oliva et al. 2002). Water is the most limiting physical factor in the ecosystem (Maass et al. 2005). Land in the municipality of La Huerta is dedicated partly to agriculture $(24.74 \%)$, pasture $(1.75 \%)$, and residential use $(0.17 \%)$; the rest consists of forests, jungles, and lakeside vegetation (72.7\%) (INEGI 2009, 2015).

We worked in the nine "ejidos" adjacent to the reserve (Fig. 1). An ejido is a semicommunal form of land possession that existed until 1992 but since then has been given over to private land tenure. These ejidos stretch from the coast up to an altitude of $332 \mathrm{~m}$ above sea level (INEGI 2010), with areas of rolling hills and varying levels of both agricultural and ranching productivity that is determined by soil type and water availability. The combined population of all these ejidos is 4597 inhabitants $(20 \%$ of the total population of the municipality of La Huerta), and individual ejido populations vary between 19 and 1300 inhabitants (INEGI 2010). Historically, property titles have been assigned to men, known locally as ejidatarios; they have possession of the land and are involved in productive management activities (Lazos-Chavero et al. 2016). Although, since 1992, the law allows the possession of land by women, the rural family model still supports traditional practices where male ownership and management of land dominate (Almeida 2012, Vázquez-Garcia 2015). A total of 957 ejidatarios and their families live in the nine ejidos studied (RAN 2016), of whom 189 were beneficiaries of financial incentives for promoting ranching activities in 2014 (SAGARPA 2016). These financial incentives are applied at the federal level. For example, the federal policy "Livestock Productivity Stimulus Program (Programa de Estímulos a la Productividad Ganadera, PROGAN)" is a stimulus for buying cattle. But the local inhabitants also demand the generation of other policies that combine productive development with environmental conservation and territorial planning (Cano-Castellano and Lazos-Chavero 2017).

The ejidos included in this study were created between 1950 and 1975 within the framework of the "March to the Sea" (RevelMouroz 1972, Castillo et al. 2005, 2009), a national policy aimed at colonizing the coasts of the country. Ejido land was distributed by the National Agrarian Reform (Castillo et al. 2009). In 1992, agrarian reform was abolished, and land ownership was transformed from collective forms of property to private (Warman 2003), thereby reducing the frequency and importance of collective decisions. The consequent increase in individual decision-making drove a change in the collective action and reduced conformity concerning the use of some common resources, such as the forest. Nevertheless, for scarce and vital common resources such as water, the people maintained their collective agreements (Schroeder and Castillo 2013).

Academics have been present in the area since the creation of the Chamela Biological Station by the National Autonomous University of Mexico (UNAM) in 1971, but especially during recent decades, with the initiation of projects that linked the station, the university, and the local population (Castillo et al. 2005). A solid basis for further indepth exploration concerning priorities for ecosystem services has been established through research into the environmental history of different ejidos and towns (Castillo et al. 2009), perceived ecosystem services (Godínez-Contreras 2003, Martínez-Hernández 2003, CorderoCueva 2005, Maass et al. 2005, Gómez-Bonilla 2006, SolórzanoMurillo 2008, Sánchez-Matías 2010), their ecological value (Saldaña-Espejel 2008, Trilleras-Motha 2008, Flores-Díaz 2015), their socioeconomic value (Naime-Sánchez 2016), and their management (Cohen-Salgado 2014, Urgachetea-Salmerón 2015).

\section{Data collection}

We interviewed 27 cattle ranchers between February and June 2015; they represented approximately $15 \%$ of the cattle ranchers in the region and were provided with financial incentives aimed at fostering ranching activities. We defined the group of cattle ranchers as those ejidatarios who had representation in the ejidal assembly and whose capital was invested in cattle. The sample was designed to include the greatest possible difference among individuals, all men, in the nine ejidos, in terms of age, education, occupation, and quantity of cattle, and we included 2-4 ejidatarios for each ejido. Their ages ranged between 34 and 79 years (average 62), which provided an age structure similar to that described by Torales-Ayala (2015) in his study of ranching culture in the same area. Emigration has resulted in a lack of young producers (Cohen-Salgado 2014, Torales-Ayala 2015), a phenomenon that is common not only in the study area but throughout Mexico (Nawrotzki et al. 2013). Our sample size of 27 reflected our aim to study the cattle ranchers' experiences with the ecosystem services rather than to obtain a large sample size. The positive attitudes of the cattle ranchers who participated in the indepth interviews gave us confidence in the information collected. However, the small sample size limits the statistical power of the analysis, so the quantitative results should be interpreted as exploratory rather than conclusive.

Interviews were individual and took place in the cattle ranchers' houses. We initially selected a group of seven cattle ranchers with whom we had maintained frequent contact, who had participated in other academic research projects, and with whom trusting relationships had been established. This rapport gave us access to each individual's point of view (Tickle-Degnen and Rosenthal 1990). Initiating interviews with key cattle ranchers had a snowball effect (Faugier and Sargeant 1997), meaning that interviews were not completely independent of each other. The sample revealed its saturation point as soon as referenced names began to be repeated.

Interviews were organized in the following way: (1) opening with questions that referenced the photographs, (2) looking at drawings of perceived services on cards, (3) ranking drawings with ecosystem services prioritized over a horizontal gradient, and (4) completing a sealed questionnaire. Data collection and analyses combined qualitative and quantitative approaches (Driscoll et al. 2007). This mixed-method strategy permits complementary information to be obtained and results from both methods to be triangulated (Bryman 2006). Interviews were conducted in Spanish, the cattle ranchers' mother tongue. The interviews lasted on average $1 \mathrm{~h} 20 \mathrm{~min}$ (ranging from $45 \mathrm{~min}$ to $2 \mathrm{~h}$ and $10 \mathrm{~min}$ ) and were recorded in audio form (24 of the 27) as long as prior authorization had been given by the interviewee. When the audio recording was not possible, we took notes. 
Open interviews and photographs

In order to reveal ecosystem services as perceived by cattle ranchers and to understand their productive activities, we used 12 photographs that covered a wide variety of landscapes where cattle ranchers live (Appendix 1.1). The authors selected the photographs based on their more than 15 years of field observations and scientific work in the region. The photographs depicted diverse types of ecosystem services. Referring to each color photograph, printed on $19 \times 21 \mathrm{~cm}$ paper, we asked, "What benefits do you observe here?" We used the term "benefit" rather than "services" because we considered it to be more general and comprehensible to interviewees. Photographs were presented to visually motivate the identification of services because images have been shown to recapture knowledge and memories from past life experiences (Harper 2002, Berbés-Blázquez 2012), unlike interviews based solely on words. However, unintended biases could have emerged from the properties of the pictures. The amount of light or detail in each photo can contribute to emphasizing the perception of specific components. All photographs were shown to all cattle ranchers. We acknowledge that each cattle rancher may have had a different perception of the same photograph (Beilin 2005, Sherren et al. 2010). Rather than eliminate this subjectivity, we wanted to allow it to be expressed. We noted any services mentioned by interviewees as they viewed each photograph. In this way, we obtained a list of ecosystem services as expressed in the daily language of the interviewee.

\section{Drawings of perceived services}

When pertinent, the nomenclature of the perceived services was standardized to resemble that already reported for the region. We relied on 17 hand-drawn cards for the team of interviewers, each representing an ecosystem service (Appendix 1.2) that had been identified in the literature for the study site (Godínez-Contreras 2003, Martínez-Hernández 2003, Cordero-Cueva 2005, Maass et al. 2005, Gómez-Bonilla 2006, Solórzano-Murillo 2008, SánchezMatías 2010). Some services (15) could be identified in some of these drawings (Appendix 1.2), while others (22) were drawn on the spot by the interviewers.

\section{Ranking of priorities and the reasons associated with the importance of prioritized services}

In order to identify priorities for ecosystem services, we implemented a ranking that consisted of placing the drawn cards over a horizontal gradient of importance plotted on a flip chart. We discussed with the interviewee all the drawn cards (with the names of the ecosystem services) that corresponded to the services he had identified in the photographs. We presented the flip chart and explained the horizontal gradient, from the most important services (to the right, with a "smiley face") to the least important (to the left, with a "neutral face"). We helped him rank the relative importance of the different services, iteratively comparing the services to help him decide which was the most important one (see Appendix 1.2 for details). We asked him to place the cards on the flip chart, refining even more the discrimination of the relative importance of the services through their position along the horizontal gradient. We then confirmed the ordinal importance attributed by the interviewee (moving from 1, the most important, to "n," the least important) by reviewing the cards and their position in the gradient (of the flip chart) and tagging each with its respective number. This tagging was particularly important when services were grouped very close to each other on the flip chart. Regarding the service positioned in first place, we then asked, "Why is this service the most important for you?" The answer to this question enabled us to analyze the reasons associated with the importance attributed to those services.

\section{Closed questionnaire to characterize the livelihoods of the cattle ranchers}

We explored 11 variables (Appendix 2) in socio-demographic and economic traits, including age, years of education, diversity of productive activities (beside cattle ranching), place of residence, and number of cattle. We explored the relationship people had with the biological station and the academics. In this way, we evaluated the role of possible biases derived from the historical connection between local townspeople and UNAM academics, especially biologists.

\section{Data processing}

We performed two steps prior to data analysis: (1) we coded ecosystem services, as perceived by cattle ranchers on viewing the photographs, and (2) we obtained an indicator of importance for each service according to its ranking, subsequently categorized by level of importance.

\section{Coding of ecosystem services}

We retrieved the views of the cattle ranchers in order to define services according to their perceived benefits, as similar studies with other types of stakeholders have done (Berbés-Blázquez 2012, Asah et al. 2014, Klain et al. 2014, Mahajan and Daw 2016). We considered a service to consist of each benefit that proved to be significant for the cattle ranchers and that was directly provided by the ecosystem (details in Appendix 3.1) (Fisher et al. 2009, Danley and Widmark 2016). Each service was classified under a main type, applying the nomenclature proposed by MEA (2005): provisioning, cultural, regulating, and supporting.

Obtaining an indicator of importance for each ecosystem service We digitized each flip chart that was compiled with a cattle rancher during the ranking. For each service represented on the card, we distinguished two complementary data sources for assessing its value, or relative importance. The first data source was positioned along the horizontal gradient (p); the position of each card was recorded (from its center) relative to the horizontal gradient, from 0 (left, unimportant) to 1 (right, most important) on a quantitative relative scale. The second data source was the ordinal importance attributed by the interviewee (o); 1 was the most important; $n$ was the least important. Using these data, we constructed an Importance Value Index related to each service by each cattle rancher (Individual Importance Value, Appendix 3.2).

In addition, we obtained two indicators for the importance of each service as perceived by the cattle ranchers: (1) General Importance Value was calculated from the sum of all the Individual Importance Values attributed to that service by the individual cattle ranchers who mentioned it; (2) General Frequency referred to the number of mentions given to each service. The General Importance Value for each service was assigned to a level of importance, beginning with the quartile position measurements: high (100-75\%), medium (75-25\%), and low $(25-0 \%)$. In this way, we analyzed the distribution of data to identify the services most and least frequently mentioned and to characterize the average services perceptions. 


\section{Data analysis}

Mix methods ranged from multivariate statistical analysis to interpretative-qualitative analysis. Although the sample size (27) was small for a statistical analysis, we used nonparametric tests in an exploratory way, not to prove a hypothesis. The analysis allowed us to understand who among cattle ranchers said what and to identify the variables that could explain the differences in ecosystem services priorities among individuals.

\section{Ecosystem services ranking}

In order to analyze the priorities for services perceived by cattle ranchers, we worked with the indicators General Importance Value and General Frequency. A "bubble" chart of the relationship between the identity of the service, its frequency, and the General Importance Value permitted us to compare service rankings by assessing the indicators with data dispersion displayed on two axes to which an additional data point was added, represented by the size of its "bubble."

\section{Livelihood}

Our analysis of the socio-demographic variables of each individual was based on a multiple correspondence analysis (MCA), which allows the use of nominal and categorical variables (Lê et al. 2008) (see Appendix 4). This was complemented by a group hierarchical analysis, which produced two subgroups of cattle ranchers based on the variables with the greatest weight, as these explained the multivariate (Appendix 4).

\section{Association between priorities and livelihood}

In order to identify associations between priorities and sociodemographic characteristics, we used services with a General Importance Value that corresponded to the level of high importance. First, we used a nonmetric multidimensional scaling (NMDS) to explore whether the Individual Importance Value of the services grouped themselves in agreement with the livelihood of the individual cattle rancher. This approach allowed us to identify the socio-demographic variables of the cattle ranchers that were associated with the ordering of priorities (Oksanen et al. 2008). Second, we used a Chi-square test to identify whether the subgroups of cattle ranchers, differentiated by their livelihoods (as identified from the MCA), differed in the way they ranked regulating/supporting/cultural versus provisioning services.

All analyses were performed with R.3.2.2 (R Development Core Team 2015), using the vegan and FactoMineR packages.

\section{Reasons associated with the importance attributed to prioritized} services

For our qualitative analysis, we used an interpretativeconstructivist approach to ensure that the subjective point of view of each individual was respected by paying heed to their narratives and feelings (Mills et al. 2006, Montes de Oca-Barrera 2016). The information that emerged from each individual's narrative was arranged into categories of analysis (Mills et al. 2006, Gibbs 2012). For a meticulous interpretation of results, we focused on the three most important services for most (17 of the 27) of the interviewees. Later, the generality of these results was confirmed when the prioritized services for the other 10 interviewees were considered. Likewise, we explored qualitatively whether the factors that influenced priorities differed among cattle ranchers with different livelihoods.

\section{RESULTS}

Services perceived and prioritized by the cattle ranchers Cattle ranchers living in this tropical dry forest landscape perceived 54 ecosystem services in total (Table 1). On average, each cattle rancher recognized 14 services (this number ranged between 8 and 21). Among the most common perceptions, a number of provisioning services linked to ranching activity stood out, such as "pasture" and "water" for livestock, and products obtained from maize cultivation that can be used either as forage for livestock or as food for domestic use. A second group of perceived services was strongly linked to maintaining the forest; for example, "rain" and the "forest's interaction with the rain," also "life" as a benefit that extends to personal existence and was evoked by the forest. Furthermore, "habitat" and "air quality" and "scenic beauty" were commonly perceived.

Five cattle ranchers $(\mathrm{CR})$ recognized that the provisioning services are a consequence of some supporting and regulating services: "grazing from the forest" was related to the tree canopy or presence of forest vegetation (CR6); services derived from crops (e.g., "food derived from maize," "cultivated fodder") were a consequence of "soil fertility" (CR5, CR19). Other cattle ranchers also recognized interrelationships, especially when talking about primary productivity and the seasonality of the tropical dry forest (CR18), or about more complex ecosystem processes, such as decomposition and the soil fertility linked to seasonality (CR13) (see Appendix 5.2).

The most important ecosystem services (identified from General Importance Value) (Fig. 2) included mainly provisioning services $(50 \%)$; the rest combined some cultural, regulating, and supporting services. Services with the greatest importance values were "pasture for livestock," followed by "water for livestock," and third, "rain." Rain, associated with precipitation and the presence of clouds, was perceived differently from water that cattle drink or from the recharging of groundwater.

Some frequently mentioned ecosystem services were not necessarily considered the most important, or vice versa (Appendix 5). Scenic beauty, a service coded as "aesthetic appreciation of nature and landscape," was perceived by 21 of the 27 cattle ranchers; nevertheless, only one person placed this service among their priorities, citing the possibility of undertaking ecotourism projects. Although other cattle ranchers mentioned their interest in implementing projects on their properties, scenic beauty was not considered a priority service. Referring to this service, one of the interviewees stated, "A farmer can't eat 'pretty'; he does not earn from tourism" (CR7, 73 years old). "Pasture for livestock" was mentioned by 26 (of the 27) cattle ranchers, whereas only 5 ranked it first. "Rain" was mentioned by 16 cattle ranchers, and 13 put it in first place. Although grazing is important for ranching activity, it obviously depends on rain. The cattle ranchers recognize that rain is a basic service supporting other services (such as the water stored in the paddocks or accessed from the natural outcrops on their land), as well as other regulating services (for example, the recharging of groundwater).

\section{Priorities and livelihood}

Prioritized services were grouped into two large categories: provisioning, and an amalgamation of cultural, regulating, or supporting (Fig. 3b) (NMDS stress: 0.22). The provisioning 
Table 1. Total of ecosystem services identified by the 27 cattle ranchers. The services ranked by importance are presented (1 to 54 ), with descriptions of each service and the coding by type following the nomenclature of MEA (2005). The expressions used by the cattle ranchers for referring to the perceived benefits from the photographs are described.

\begin{tabular}{|c|c|c|c|c|}
\hline No. & Ecosystem service & Description & Type MEA & Perceived benefits \\
\hline 1 & $\begin{array}{l}\text { Pasture for } \\
\text { livestock }\end{array}$ & $\begin{array}{l}\text { Nourishment produced as fodder for the livestock } \\
\text { by cultivating different species of grasses }\end{array}$ & Provisioning & $\begin{array}{l}\text { Grass for livestock, cattle pasture, grazing, pasture for livestock, food for } \\
\text { the livestock, good pasture, immediate pasture }\end{array}$ \\
\hline 2 & Water for livestock & $\begin{array}{l}\text { Water that the livestock drinks, stored in troughs. It } \\
\text { can be provided by seasonal rain, extracted from } \\
\text { outcrops in their own lands, captured in and } \\
\text { transported from bodies of running water. }\end{array}$ & Provisioning & $\begin{array}{l}\text { Water for livestock, watering trough, lagoon, reservoir, basin, trough, water } \\
\text { for the cows, "ojo de agua," water good for the livestock, rainwater for the } \\
\text { livestock, contained water for the livestock, stream for the livestock }\end{array}$ \\
\hline 3 & Rain & Precipitation & Supporting & $\begin{array}{l}\text { Clouds, rain (storm), an abundance of water, "it's almost raining," "better } \\
\text { that it rains than it doesn't rain," signs of rain }\end{array}$ \\
\hline 4 & $\begin{array}{l}\text { Food derived from } \\
\text { maize }\end{array}$ & $\begin{array}{l}\text { Nourishment for human consumption derived } \\
\text { from the fresh fruit of maize (corn) or the dry grain } \\
\text { producing tortilla dough and other foods }\end{array}$ & Provisioning & $\begin{array}{l}\text { Corn to eat, maize for "tortillas," (milpa) food for humans, corn crop, } \\
\text { maize crop, maize for household expenditure, maize for feeding people, } \\
\text { corn for own consumption, food for everyone, maize for food for one }\end{array}$ \\
\hline 5 & $\begin{array}{l}\text { Aesthetic } \\
\text { appreciation of } \\
\text { nature and the } \\
\text { landscape }\end{array}$ & $\begin{array}{l}\text { Appreciation of the beauty observed in nature, } \\
\text { forest, or coastal landscape }\end{array}$ & Cultural & $\begin{array}{l}\text { Pretty landscape, pretty jungle, pretty forest, to see the pretty ocean, } \\
\text { attractive panorama, impressive panoramic view, colors and life, } \\
\text { magnificent, pretty lake, beauty, scenic beauty, to admire the water } \\
\text { (lagoon), landscape as pretty as a postcard, pretty grove, attractive } \\
\text { blooming trees, to see flowering "is like seeing the ocean at sunset" (among } \\
\text { others) }\end{array}$ \\
\hline 6 & Cultivated fodder & $\begin{array}{l}\text { Food obtained for the livestock from the stubble of } \\
\text { the harvested maize crop or from grain crops such } \\
\text { as sorghum }\end{array}$ & Provisioning & $\begin{array}{l}\text { Food for animals, cultivation of pasture, production of maize to feed } \\
\text { livestock, sowing: food for livestock, fodder for livestock in the dry season, } \\
\text { silo, maize for grazing }\end{array}$ \\
\hline 7 & $\begin{array}{l}\text { Forest-rain } \\
\text { interactions }\end{array}$ & $\begin{array}{l}\text { Interaction between the vegetation (of the } \\
\text { continuous forest), regional topography, and the } \\
\text { rain }\end{array}$ & Supporting & $\begin{array}{l}\text { Water comes from the hills because there are more trees and brings water } \\
\text { to the towns, forest calls to the water, water-rain reestablishes the forest, } \\
\text { jungle retains water, trees call the water, they call the rain }\end{array}$ \\
\hline 8 & Habitat & The forest as a space where the wildlife lives & Supporting & $\begin{array}{l}\text { Habitat for wildlife (deer, wild boar), animals that live there and reproduce, } \\
\text { they raise animals, land for wild animals, place for the birds to live, where } \\
\text { the animals hide, place for birds }\end{array}$ \\
\hline 9 & $\begin{array}{l}\text { Protection of } \\
\text { nature }\end{array}$ & $\begin{array}{l}\text { Attitude referred to as "to preserve or protect" the } \\
\text { continuous forest, the beauty of the forest, the } \\
\text { species }\end{array}$ & Cultural & $\begin{array}{l}\text { Animals that are preserved, preserve the earth, woodland to preserve, for } \\
\text { forest conservation, woods (trees) to protect, to save wild animals, to } \\
\text { protect fish (among others) }\end{array}$ \\
\hline 10 & Wood & $\begin{array}{l}\text { Trees that provide wood for the construction of } \\
\text { furniture, houses, and work tools }\end{array}$ & Provisioning & $\begin{array}{l}\text { Good wood, big wood, wood for construction, woodlands, timber-yielding } \\
\text { trees, wood for building tools, fine wood }\end{array}$ \\
\hline 11 & Air quality & $\begin{array}{l}\text { "Oxygen" is related to the presence of trees and } \\
\text { expresses the air quality as clean or purified air }\end{array}$ & Regulating & $\begin{array}{l}\text { Trees (give) good oxygen, oxygen for animals and humans, trees for } \\
\text { (contributing) oxygen, vegetation purifies the air (among others) }\end{array}$ \\
\hline 12 & $\begin{array}{l}\text { Water for life } \\
\text { (wild) }\end{array}$ & $\begin{array}{l}\text { Water tributaries for the wildlife, also relates to the } \\
\text { use the wild fauna makes of water stored for the } \\
\text { livestock }\end{array}$ & Supporting & $\begin{array}{l}\text { Water so that the plants grow, water for wild animals, for other animals: } \\
\text { deer, mountain tiger, wild boar; runoff that maintains the flora }\end{array}$ \\
\hline 13 & Life & $\begin{array}{l}\text { Common expression between the townspeople that } \\
\text { links water to the existence of living beings and to } \\
\text { life itself }\end{array}$ & Cultural & $\begin{array}{l}\text { Water is life, part of life, life for animals, life for people, rain is life, } \\
\text { moistens the forest, water for everyone is half of life the other half is } \\
\text { oxygen }\end{array}$ \\
\hline 14 & $\begin{array}{l}\text { Food derived from } \\
\text { fishing }\end{array}$ & $\begin{array}{l}\text { Nourishment for human consumption derived } \\
\text { from fishing in freshwater or marine ecosystems }\end{array}$ & Provisioning & $\begin{array}{l}\text { Lagoon (breeding of "tilapia"), fish to eat, fish as food, stream (extraction } \\
\text { of) fish, shrimp, ocean to fish for food }\end{array}$ \\
\hline 15 & Shade for livestock & $\begin{array}{l}\text { Microclimate regulation; associated with the trees } \\
\text { that they left in the paddocks or patches of the } \\
\text { forest where livestock rest }\end{array}$ & Regulating & $\begin{array}{l}\text { Shade trees, shade for animals, shade, "nap-sisteo" of livestock, to shade, } \\
\text { covering in good condition (provides) shade }\end{array}$ \\
\hline 16 & Coolness & $\begin{array}{l}\text { Climate regulation under forest canopy or elevated } \\
\text { sites with air currents }\end{array}$ & Regulating & $\begin{array}{l}\text { Magnificent climate, fresh wind, breezy high terrain, cool place, cool grove, } \\
\text { cool jungle, cool weather coolness, makes the hot weather more bearable }\end{array}$ \\
\hline 17 & $\begin{array}{l}\text { Water usage for } \\
\text { humans }\end{array}$ & Water for human consumption & Provisioning & $\begin{array}{l}\text { Water for one, drinkable water, for use of the human population, for } \\
\text { humans, for the town }\end{array}$ \\
\hline 18 & $\begin{array}{l}\text { Regulating the } \\
\text { flow of water }\end{array}$ & $\begin{array}{l}\text { Riverside vegetation associated with the } \\
\text { maintenance of water flow }\end{array}$ & Regulating & $\begin{array}{l}\text { The current is maintained (of the river), vegetation (that) protects the } \\
\text { spring and the slope, riverside vegetation (protects so the) water does not } \\
\text { evaporate, hillside ravines have a lot of water }\end{array}$ \\
\hline 19 & $\begin{array}{l}\text { Aesthetic } \\
\text { appreciation of } \\
\text { wildlife }\end{array}$ & Appreciation by observing the wildlife & Cultural & $\begin{array}{l}\text { To see wildlife, "tigron" is beautiful to see, many types of attractive } \\
\text { animals to see, birds are look good, fauna is interesting, it is nice to see } \\
\text { animals }\end{array}$ \\
\hline 20 & $\begin{array}{l}\text { Potential aesthetic } \\
\text { appreciation for } \\
\text { others }\end{array}$ & $\begin{array}{l}\text { Appreciation of the landscape so that others } \\
\text { (tourists) enjoy it }\end{array}$ & Cultural & $\begin{array}{l}\text { Attractive (for the) tourism, to preserve (for the) tourism, tourist } \\
\text { attraction, ocean (for the) tourism (gives employment to the people, the } \\
\text { area is a sleeping giant), tourism admires nature, touristic panoramic view } \\
\text { (among others) }\end{array}$ \\
\hline 21 & Soil protection & $\begin{array}{l}\text { Vegetation associated with protecting the soil } \\
\text { erosion }\end{array}$ & Regulation & $\begin{array}{l}\text { Deep gully with trees to control the erosion through branches that retain } \\
\text { the soil, revegetation of trees holds the soil, vegetation retains the earth } \\
\text { (and does not clog the bodies of water) }\end{array}$ \\
\hline 22 & $\begin{array}{l}\text { Aesthetic } \\
\text { appreciation of the } \\
\text { landscape for } \\
\text { oneself }\end{array}$ & $\begin{array}{l}\text { Appreciation of beauty for enjoyment and for rest } \\
\text { for oneself }\end{array}$ & Cultural & $\begin{array}{l}\text { A house on the point (pretty hill to live on, to relax, to rest, tranquility, a } \\
\text { little ranch for living well) }\end{array}$ \\
\hline 23 & $\begin{array}{l}\text { Grazing from the } \\
\text { forest }\end{array}$ & $\begin{array}{l}\text { Fodder from the native vegetation, which the } \\
\text { livestock obtain from foraging under the tree } \\
\text { canopy }\end{array}$ & Provisioning & $\begin{array}{l}\text { Foliage for livestock, forage, green area (high forest) is "grass" for cows, } \\
\text { trees for fodder, livestock eat fruit from trees, vegetation that grows in the } \\
\text { dam is fodder, to pasture livestock on the forest, trees that give leaves for } \\
\text { livestock (among others) }\end{array}$ \\
\hline
\end{tabular}


Aural appreciation Enjoyment of the bird song of the forest of the fauna Post

Soil moisture and the vegetation

Interactions and properties of the

ecosystem

28 Recreational

activities in nature Recreation in the forest and other natural spaces,

Food derived from for oneself and the family, in terrestrial ecosystem

wild plants or

animals

obtained by hunting wildlife or collecting frui from the forest

30 Food derived from Nourishment for human consumption derived ranching from ranching production

31 Appreciation of Appreciation of rural landscape (crops, fields, the positive ranches, towns

qualities of

productive

environments

32 Multiples use for

wild species

Multiple products from the forest, obtained under different management practices (e.g., the Units of Environmental Management [UMA]).

33 Recharging of groundwater

Fire wood

$\begin{array}{ll}34 & \text { Fire wood } \\ 35 & \text { Recreational }\end{array}$ Replenishment of the aquifers

Recreation on the beach and other natural

activities in bodies for oneself and the family, in coastal and

of water and the freshwater ecosystem

ocean

36 Soil fertility

Soil fertility for the pasture and crops observed in the productivity of the grass on flat terrain

37

Environmental Favorable conditions for the growth of forest conditions for wild vegetation

plants

$38 \quad$ Water for

irrigation

39

Regulating water Quality of clean and oxygenated water

quality

Control of pests

Carbon capture

Fallen leaves and

fertilizer in the soil

Food for other

domestic animals

Future knowledge

of the animal life

Productivity

Water (from rain, water plantations (fruit) and crops

Regulation of the species populations considered pests

Wood vegetation that captures atmospheric carbon

Foliage that is involved in the processes of

decomposition in the ecosystem

Nourishment for domestic animals derived from

the maize crop knowledge

Increase in the production of fruit and pasture

during rainy seasons

46 Aural appreciation Appreciation of the sound of water in the rivers

of water

Seasonality (dry)

Seasonal dry and rainy periods, characteristics of dry tropical forest

Perches for birds Trees for perching, dispersing seeds

Food for wildlife Nourishment that wildlife eats derived from the crops or native plants

Health Sensation associated with different landscapes

Product extracted from the plots with rocky

outcropping, used for construction

Production of cow breeds for milking

Dairy cattle

Happiness

Spirituality

Emotion associated with different landscapes
Cultural

To listen to the birds, birds (give) joy, bird song

Provisioning

Post, trees for posts

Supporting

Jungle (on the border of the crops) benefit for the corn plants, moisture in the earth, coverage in good condition (next to a crop provides) moisture for the land, trees that keep the corn plants moist, all green (the crop indicates) humidity (in the soil)

Supporting

Manglar regulates (the) ecosystems (coastal), wild animals that maintain

the biological balance, fauna (associated with) biological control by regulation the populations

Cultural

To go for a walk, recreation, to spend a day in the countryside, enjoy nature, walk (through the forest with blooming trees), enjoy

Provisioning Wild animals as food, regulated hunting for human consumption and not for business, meat "de monte" to eat, trees that bear fruit (for food)

Provisioning Livestock produce milk and meat; cheese for food; and for commerce

Cultural

Pretty corn plants, pretty pasture, nice ranch, beauty "like this I want my ranch," (value through the work in maintaining it), pretty the pasture

Provisioning

Honey from bees, medicinal plants, wildlife as pet, animals benefit humans (e.g., UMAs)

Regulating

Water tables are filled; (regeneration of the forest) reestablishes the groundwater layer, increases the infiltration

Provisioning Fire wood

Cultural

To fish near the ocean, sports fishing, food on the beach, to take a walk and take a dip, island for (to go to) to spend some time

Regulating

Good soil "here good grass can be preserved," fertile from the green, form of flat land (helps that) the soil does not erode, fertile earth (it gives everything, it does not have chemical fertilizer)

Supporting Cool and moist for trees, humidity for the growth of plants

Provisioning

Water for product: fodder, grass, vegetation; water for watering, for pasture, watering field, in season it provides vegetables, rain renews the crops

Regulating (Vegetation retains the earth and) it does not clog the body of water (e.g., the dam)

Pest control

Regulating

Regulating

Regulating

Forest in regeneration (has a high rate of) carbon capture

Fallen leaves in the soil (to look upon), "varal" or sticks, fallen foliage creating fertilizer for trees

Provisioning Maize for the chickens, for the horses

Cultural To preserve the animals so that the grandchildren know them, grandchildren will not see the animals that is important to know

Supporting It rains a lot (then) more rain more water and, more water more fruit from the trees; water in seasons provides fruit, water in seasons provides greenery

Cultural Sound of water

Supporting Dry, as a natural cycle of the dry tropics; "varal"

Supporting Tree perches (for birds), fruit trees for birds, dispersion for birds

Supporting Food for all types of animals (wild): grazing for deer, fruit trees for feeding

wild animals

Cultural Health

Provisioning Stone, rocks for cement

Provisioning Milk cow

Cultural Happy

Cultural Nice (as a present) religious services (red triangles) were close together on the right side of the plot. In contrast, cultural, regulating, and supporting services (gray, blue, and green triangles) appeared to be more dispersed, and were positioned toward the left of the plot.

The two groups of services were associated with different types of forest cover. Generally, interviewees associated provisioning services with the productive environment of ranching. In contrast, they associated most cultural, regulating, and supporting services with the tropical forest.

Differences in priorities for ecosystem services were associated with livelihood. Education $\left(r^{2}=0.26, P=0.03\right)$ and diversity of productive activities $\left(r^{2}=0.24, P=0.04\right)$ were significantly related 
Fig. 2. Total ecosystem services ( 1 to 54 circles) recognized by 27 cattle ranchers. The services were ranked by frequency (quantity of mentions) and by the value of importance (size of the circle). The colors correspond to the division of the services by type, following the nomenclature of MEA (2005). The names of the 15 services with the greatest level of importance are indicated; see Table 1 for the remaining services.

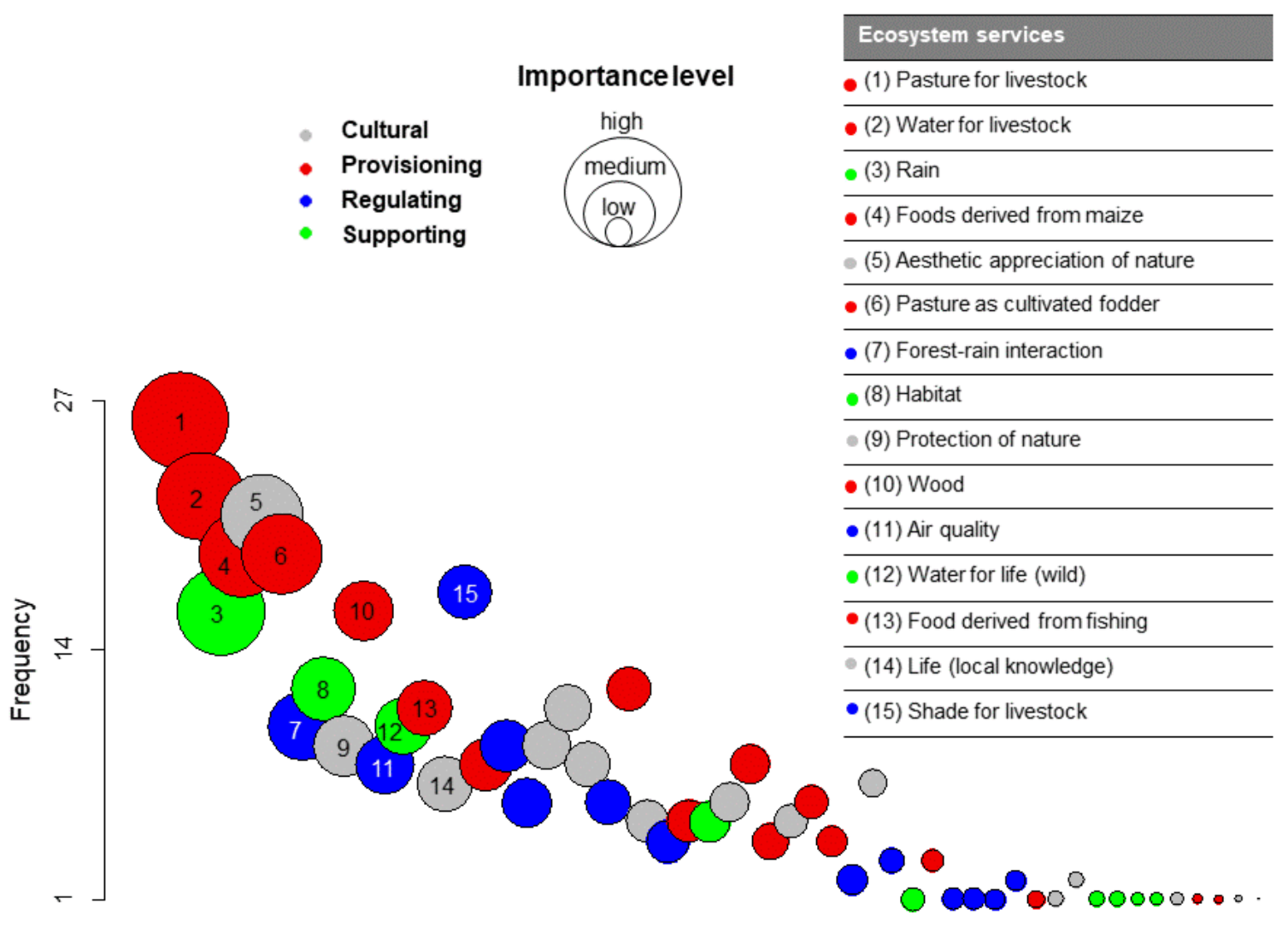

ー

Ecosystem services

to differences between the cattle ranchers in terms of priorities for services (Fig. 3a). Subgroup 1 (Fig. 3c, black crosses) was characterized by the highest education level and diversity of productive activities, and members in this group tended to prioritize cultural, regulating, and supporting types of services ( $70 \%$ of mentions as opposed to $40 \%$ of mentions from subgroup 2 [Chi-square $=8.18, \mathrm{df}=1, P=0.004]$ ). Subgroup 2 (Fig. 3c, red crosses) was characterized by a lower education level and less diversity of productive activity, and revealed no distinguishing priorities between categories of ecosystem services.

Nevertheless, a group of provisioning services strongly associated with ranching activities was prioritized by all the interviewees, irrespective of their livelihoods (Chi-square $=1.99, \mathrm{df}=1, P=$ 0.158 ). Pasture and water for cattle were prioritized by individuals at various levels of education and with different productive strategies.

\section{Reasons associated with the importance attributed to prioritized} services

Importance attributed to the three most important services tended to cluster around three main categories: (1) work, (2) well-being, and (3) interdependence (Fig. 4). "Work" referred as much to the activities each individual performed to secure his economic support as to the different management practices that ranching activity entailed (quotations A-I, Table 2 and Appendix 6.1). The importance of "pasture for livestock" was justified because it secured the livelihood of the cattle rancher (for example, quotation A, Table 2), while "rain" was justified as a part of management practices. These practices involved replenishing water bodies from which water is extracted for consumers (for example, quotation $\mathrm{G}$, Table 2) or for watering plantations. Water is also used to maintain seasonal crops that are exploited for grazing (for example, quotation I, Table 2). The work included explicit reference to material well-being. The material well-being was particularly apparent when a cattle rancher linked rain to the 
Fig. 3. Order of the most important ecosystem services (triangles) that were prioritized and their association with the profile of the cattle ranchers (crosses, nonmetric multidimensional scaling [NMDS] stress: 0.22). (A) The highprioritized ecosystem services located on the left side of the graph are associated with education and other productive activities (blue arrows) of the cattle ranchers. (B) The 15 ecosystem services are categorized into types: provisioning (red), cultural (gray), regulating (blue), and supporting (green). Ecosystem services numbering from 1 to 15 appear in Fig. 2. (C) The cattle ranchers in panel A (crosses) are highlighted and identified by the subgroup to which they belong according to multivariate correspondence analysis (MCA): Subgroup 1 (black crosses) includes cattle ranchers with the most education and diversity of productive activities. Subgroup 2 (red crosses) includes cattle ranchers with the least education and diversity of activities. See Appendix 4 for more details of the MCA.
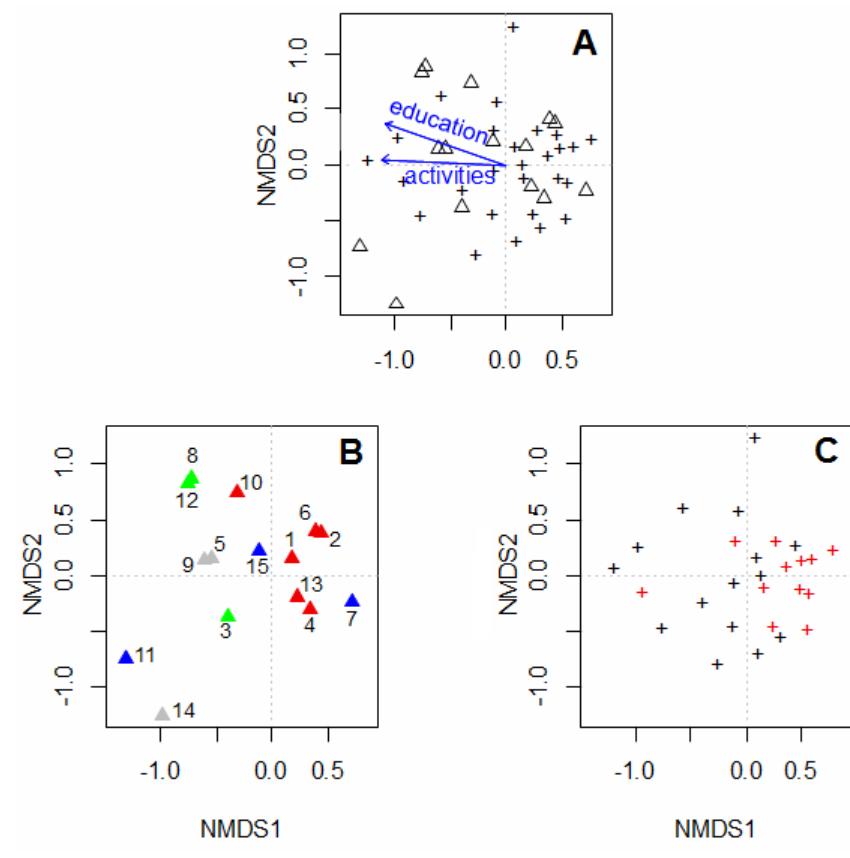

provision of water for livestock sustenance and to gaining access to alternative goods that offered him a better quality of life (quotations E and L, Table 2).

"Well-being" included the well-being of livestock (considered as the degree to which animals were content), the material well-being of people (referred to as possessing or gaining access to material goods in order to live well), subjective well-being (expressed as emotions or sensations, such as liking something, feeling happy, being content), and social well-being (referred to as well-being extended to society, transcending individual well-being). "Pasture" and "rain" were important for the well-being of the livestock (quotations $\mathrm{J}$ and $\mathrm{K}$, Table 2 and Appendix 6.1), considering that a healthy, well-fed animal is content. In the dry season, lack of grazing creates problems, and cattle ranchers need pasture or other reserves to feed the cattle. One cattle rancher stated that his happiness depended on seeing his animals happy,
Fig. 4. Reasons of importance granted to the three services most prioritized by the group of cattle ranchers. The coded reasons (in boxes) from the given responses (in colored circles) for the ecosystem services ("Pasture" and "Water" for livestock with red circles, and "Rain" with green circles) given first place for importance by 17 of all interviewed cattle ranchers. The letters inside the circles correspond to the quoted responses of these cattle ranchers in Table 2 (and Table A6.1). The colors of the circles represent the type of service. Light green in "Rain" represents two services recognized as important ("rain and recharged groundwater along with other services" and "forestrain interaction"), both of which support the new reason of importance associated with the social well-being category; see quotation $\mathrm{O}$ in Table 2 and $\mathrm{O} *$ in Table A6.1.

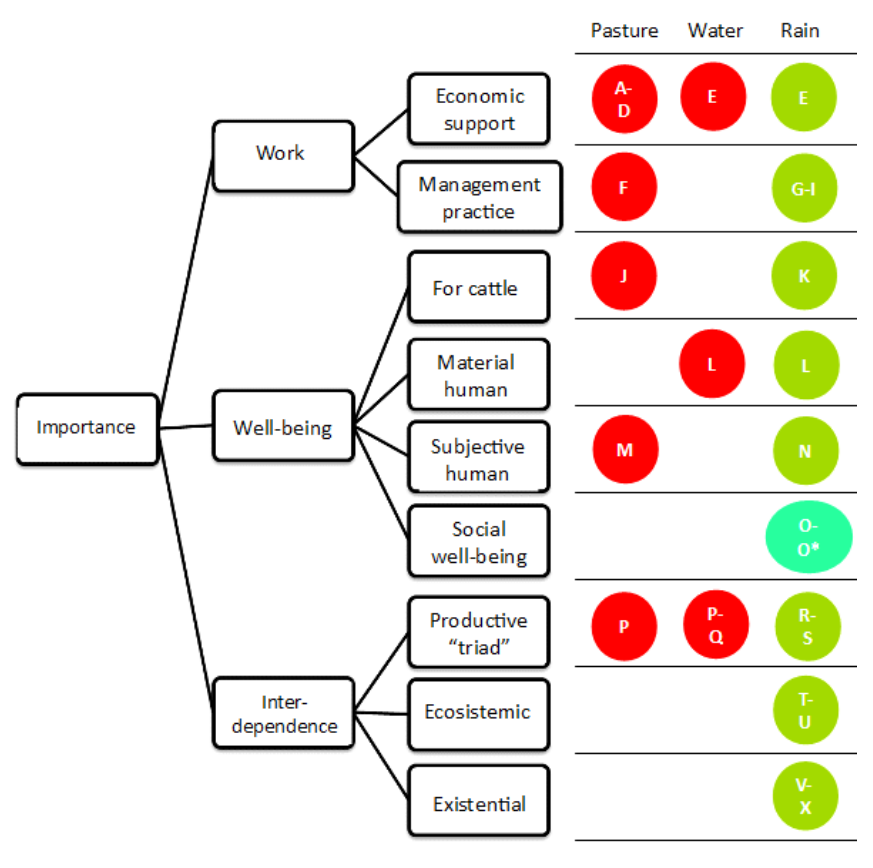

thereby indicating a deep emotional relationship with his livestock (quotation M, Table 2).

"Interdependence" comprises three elements: a productive triad, ecosystem relationships, and existence. The productive triad is pasture-water-cattle (quotations $\mathrm{P}-\mathrm{S}$, Table 2 and Appendix 6.1) because these are considered inseparable. Each of these elements is equally important and explicitly depends on the presence of the other two (quotations P and Q, Table 2). The availability of "water for livestock" in the paddock depends on the rain, as does pasture maintenance (quotations $\mathrm{R}$ and S, Table 2 and Appendix 6.1). The importance of "rain" was corroborated both in the factors influencing ecosystem relationships and as contributing to the existence of life itself (quotations T-X, Table 2 and Appendix 6.1). Ecosystem relationships reflect the view of the role of rain in habitat maintenance for wildlife and in maintaining productivity, or greenery, in the ecosystem (for example, quotation T, Table 2). Finally, rain permits life to exist (for example, quotation $\mathrm{V}$, Table 2). 
Table 2. Quotations about the importance attributed to the most important services prioritized by the cattle ranchers. Each textual quotation (A-X) corresponds to an ecosystem service prioritized by each cattle rancher (CR) (see Table A6.1 for additional quotations). The reasons of importance are codified in three large categories (Fig. 4). Each reason of importance is discussed, and the context that supports the interpretation of the categories that emerged from these reasons is given.

\begin{tabular}{|c|c|c|c|}
\hline Quotation & Ecosystem service & Reasons of importance & Commentary and context \\
\hline A & Pasture for livestock & "For me this is life, the cattle." CR22 & $\begin{array}{l}\text { Benefit for developing as a producer. He obtains his economic } \\
\text { support from ranching work. }\end{array}$ \\
\hline $\mathrm{E}$ & Rain - water for livestock & $\begin{array}{l}\text { The rain and the water (provided for the livestock) } \\
\text { permit him to sustain his ranching activity.... CR } 20\end{array}$ & $\begin{array}{l}\text { Rain is first linked to water for the livestock, which supports } \\
\text { ranching activity as work and livelihood (see relation to well- } \\
\text { being, quotation L). }\end{array}$ \\
\hline G & Rain & Brings water and helps the ranching activity. CR1 & $\begin{array}{l}\text { The rain fills the bodies of water. A management practice } \\
\text { involves moving ("carry") the water to the troughs of the } \\
\text { paddock. }\end{array}$ \\
\hline I & Rain & $\begin{array}{l}\text { "When the rain falls (and) it benefits us because the } \\
\text { trees, when there is a plantation, then...(water } \\
\text { themselves without the necessity of doing it oneself)." } \\
\text { CR5 }\end{array}$ & $\begin{array}{l}\text { In a plantation of fruit trees, watering by the rain is beneficial } \\
\text { instead of watering with buckets, a physically taxing practice. } \\
\text { The fruit plantation was viewed as an activity complementary } \\
\text { to ranching. }\end{array}$ \\
\hline $\mathrm{L}$ & Rain - water for livestock & $\begin{array}{l}\text { This activity is related to other benefits in search of a } \\
\text { "better quality of life." CR2 } 20\end{array}$ & $\begin{array}{l}\text { (Comes from quotation E) to have a "better quality of life" is } \\
\text { associated with material well-being. For example, "a better } \\
\text { quality" refers to having enough money to gain access to } \\
\text { different goods and products. }\end{array}$ \\
\hline M & Pasture for livestock & $\begin{array}{l}\text { "I get sad if I sell one (a livestock animal). I am proud } \\
\text { that my animals are happy ...." CR26 }\end{array}$ & $\begin{array}{l}\text { Expression of emotion, sentiment toward his animals that } \\
\text { relates to their own subjective well-being (comes from quotation } \\
\text { J). }\end{array}$ \\
\hline $\mathrm{O}$ & $\begin{array}{l}\text { Rain and recharging } \\
\text { groundwater along with } \\
\text { other services }\end{array}$ & $\begin{array}{l}\text { "The importance of (services offered by forestry } \\
\text { conservation) lies in the fact that it provides benefits } \\
\text { for humanity...those (individuals) with or without } \\
\text { cattle, and whether or not they are farmers, as we all } \\
\text { need it, to survive as humans; thus, we need frequent } \\
\text { rain so that we will have resources for subsequent } \\
\text { generations. I may die at any time, but my children also } \\
\text { need it. If we continue to cut down trees, we will end } \\
\text { this beauty." CR } 15\end{array}$ & $\begin{array}{l}\text { The services offered in the preserved forest are sustained by the } \\
\text { rain. The priority for the package in which all services are } \\
\text { perceived as interrelated was an expression of support for the } \\
\text { collective human well-being. Importance is also attributed to } \\
\text { maintaining the services for future generations. }\end{array}$ \\
\hline $\mathrm{P}$ & Water for livestock & $\begin{array}{l}\text { "A paddock without water, no, doesn't work at all, and } \\
\text { with water, yes. With no water, there is no pasture...the } \\
\text { two are important (pasture and water)." CR9 }\end{array}$ & $\begin{array}{l}\text { The grassland depends on water. Both are required for ranching } \\
\text { production. A water-pasture-livestock triad is established. }\end{array}$ \\
\hline Q & Water for livestock & $\begin{array}{l}\text { "Here there is grassland but no water, there isn't } \\
\text { anything. If there is water, the pasture can water itself." } \\
\text { CR17 }\end{array}$ & Idem quotation $\mathrm{P}$ \\
\hline $\mathrm{T}$ & Rain & $\begin{array}{l}\text { "...also (rain is beneficial) for the trees of the } \\
\text { countryside. Rain falls and they start to turn green." } \\
\text { CR5 }\end{array}$ & $\begin{array}{l}\text { Rain relates to productivity and to different processes of the } \\
\text { ecosystem. }\end{array}$ \\
\hline $\mathrm{V}$ & Rain & $\begin{array}{l}\text { "...is that it gives us life...to the cattle and to us also." } \\
\text { CR14 }\end{array}$ & In an existential sense \\
\hline
\end{tabular}

The same three types of categories (work, well-being, and interdependence) were also associated with priorities for "water for human use," "food derived from maize," and "recharging groundwater"; "aesthetic appreciation" was linked to other services such as habitat and recreation. Another reason refers to social well-being, linked with "rain and groundwater recharging," "forest-rain interactions," and other supporting services linked to hydrological processes and biodiversity conservation (see quotation $\mathrm{O}$ in Table 2 and $\mathrm{O} *$ in TableA6.1). One cattle rancher stated that "the importance of (services offered by forestry conservation) lies in the fact that it provides benefits for humanity...those (individuals) with or without cattle, and whether or not they are farmers, because we all need it to survive as humans; thus we need frequent rain so that we will have resources for subsequent generations. I may die at any time, but my children also need it. If we continue to cut down trees, we will end this beauty" (quotation $\mathrm{O}$ in Table 2).

The reasons given for the importance assigned to any prioritized service differed among cattle ranchers. Rain, for example, was prioritized by most of the cattle ranchers in subgroup 1 (members had a higher education level and more productive activities), but the reasons were diverse (Appendix 6.2) and included economic support through increased agricultural production, support for life itself, and the fulfillment the ejidatario feels when the cows are happy.

\section{DISCUSSION}

Diversity of ecosystem services perceived and the local context The identification of a wide range of perceived services was consistent with that found in similar studies where services were defined by their stakeholders (Berbés-Blázquez 2012, Cáceres et al. 2015, Garrido et al. 2017). The direct beneficiaries of the ecosystems perceived a diversity of services beyond the international classifications proposed for services (e.g., MEA 2005, TEEB 2010, CICES [Haines-Young and Potschin 2013]). These perceptions did not always match those defined by experts. For example, some local stakeholders in Oregon (USA) perceived the local forests as a refuge for homeless people and a means of 
regulating urban expansion, whereas scientists tended to emphasize the role of forests as providers of wood, fuel, or carbon storage (Asah et al. 2014).

The nature of perceived services indicates that the environment is strongly tied to the cattle ranchers' livelihood. Predictably, producers perceive services related mainly to provision, and tend to prioritize them because their work and income directly depend on them (Iniesta-Arandia et al. 2014). Priorities for provisioning services tied to the productive system, such as pasture for livestock, are similar to those reported for a dry region in central Argentina (Cáceres et al. 2015) and for European regions (Albizua 2016, Garrido et al. 2017). In addition to the provisioning services benefiting the key stakeholders' own productive activity (e.g., pasture), interviewees perceived regulating services as essential for this task (e.g., shade from trees in the plots). Our data also make visible the knowledge cattle ranchers have about relationships among ecosystem services. However, it is not possible to elucidate whether the cattle ranchers recognized the links between provisioning and regulation or supporting services. The exception is the case of rain, which is basic to the support of the pasture. Previous studies have shown that local people can have high degrees of awareness about the importance of regulating services underpinning provisioning services (see e.g., Iniesta-Arandia et al. 2014, Lau et al. 2018).

Biophysical characteristics of the system also clearly affect the perception of the range of services and priorities for specific services. Rain is considered by local stakeholders to represent a clear benefit that is part of a natural system in a region strongly defined by a seasonal lack of water and with clearly marked yearly dry and rainy seasons, where in some years the rainfall is twice that of others and where it also varies spatially, with sites in the lower areas having access to much more groundwater than those on high hillsides (Maass et al. 2005). In this and previous works, inhabitants of the area consistently documented a link between the dry tropical forest and the rain (Solórzano-Murillo 2008, Mendoza-Varela 2010, Monroy-Sais 2013). Rain has a visible effect on vegetation and the whole region. Rain leads to leaf and flower production, which in turn provides food for fauna during reproductive periods (Ayala-Berdon et al. 2009, García et al. 2010). The change in the system associated with the onset of rain is thus very clear in the region and has deep significance in local knowledge (Martínez-Hernández 2003, Mendoza-Varela 2010).

The most salient biophysical particularities of the conserved ecosystem forest and its interactions with climate are clearly incorporated into the cattle ranchers' perceptions. The appreciation of life is frequently associated with the annual return of the rain and is linked to the natural life preserved by the tropical dry forest in the reserve. This appreciation of life was associated with pleasure for most interviewees in this study, as in previous studies with different stakeholders of the region (MartínezHernández 2003, Mendoza-Varela 2010). Rain thus represents a service that has importance for different cultures, as described in studies undertaken in the Chamela-Cuixmala region. Conversely, few interviewees perceived aesthetic appreciation as a possibility for the development of ecotourism in the context of future plans for the region.

The assessment of different types of knowledge, including the knowledge of smallholders, complements the views derived from service categories structured by scientists (MEA 2005, TEEB 2010, CICES [Haines-Young and Potschin 2013], IPBES-Nature's Contributions to People [Pascual et al. 2017, Díaz et al. 2018]). The perspectives of smallholders inform the way they view, acquire, and use ecosystem services and manage their local ecosystem (Asah et al. 2014, Garrido et al. 2017).

\section{Importance of ecosystem services for individuals: livelihood and generational change}

This study draws upon previous studies of local stakeholders' perceptions at the study site (Godínez-Contreras 2003, MartínezHernández 2003, Cordero-Cueva 2005, Gómez-Bonilla 2006, Solórzano-Murillo 2008, Castillo et al. 2009, Sánchez-Matías 2010). We found that priorities for ecosystem services depend on cattle ranchers' livelihoods, and that reasons assigned to the prioritized services differ among individuals. The more recent generation of local cattle ranchers perceived an opportunity to develop alternative management and to promote the forest's beauty to attract more tourists. For example, they favored improving cattle raising by enriching pastures with fodder trees and developing rural tourism associated with agricultural activities.

The social-demographic conditions in rural Mexico have changed at a very fast rate over the past four decades. Changes in priorities associated with livelihood, reflected in education levels and the diversity of activities, reveal a generational transition. While the age variable of the individuals does not explain priorities, it does reflect differences in social, economic, and technological conditions, as well as differences in individual experiences regarding these. The subgroup of cattle ranchers older than 65 generally represents inhabitants who arrived in the region between 1940 and 1970, and who, as in other parts of Mexico, had no access to formal education and thus relied on governmental incentives that promoted ranching (Lazos-Chavero 1996, Durand and Lazos 2004). They transformed the tropical dry forest in order to have a livelihood, and this is a source of pride for some older cattle ranchers (Torales-Ayala 2015). The subgroup of cattle ranchers under 65 years of age includes some who arrived in the ejidos between 1960 and 1980, and some who were born in the region. Some cattle ranchers who took possession of their ejidos at the end of the period of agrarian reform face other political and environmental conditions (Warman 2003). Most of these individuals are educated, and, in the case of the younger ones, it was their access to education that gave them access to new sources of employment and aspiration to a different lifestyle (SalasQuintanal and González-de la Fuente 2014). It has indeed been suggested that a higher level of education and higher income contribute to increasing the value stakeholders attribute to cultural, regulating, and supporting services, while reducing their demand for provisioning services (Yahdjian et al. 2015).

While some of the interviewees have had long-term interactions with academics at the Biological Reserve, we did not find that this relationship significantly affected the reported priorities for ecosystem services. Although all interviewees live within $30 \mathrm{~km}$ of the Biological Reserve, and most have indirectly interacted with academics for up to 40 years, the impact of academic research on the local knowledge has been scarcely documented (Castillo et al. 2005, Arreola-Villa 2017). The interactions of people who have different types of knowledge (e.g., local ecological knowledge, 
scientific knowledge) over the long term could be made only partially visible through our assessment.

The generational change observed here is consistent with that observed throughout Latin America and the Caribbean (FAO 2014), and has profound consequences for productive activities. Likewise, systems management has important social implications and affects the ecosystem (Albizua 2016). The new generation of young adults who have decided to remain in their birthplace not only have different priorities and aspirations than their elders but will also have a different relationship with the social-ecological system. When land remains unsold and is maintained as part of a family's legacy, this legacy is considered as capital because the forest is valued for scenic beauty and viewed as an opportunity to initiate ecosystem projects (Albizua 2016). In addition, ownership creates eligibility for payments from environmental services (Naime-Sánchez 2016). This generational change throughout Latin America underscores the importance of involving the youngest generations and taking into account their attitudes to the management of socio-ecosystems (Heras et al. 2016). Despite having interviewed only 27 people, we were able to explore the implications of generational change. The hypotheses generated by this work can be further tested in the future with a larger sample size and using research tools that focus on that goal.

\section{Importance of ecosystem services for individuals: link with ecosystems}

The importance attributed to ecosystem services varies as much between individuals as between services. Even though many cattle ranchers prioritized the same service, such as pasture or rain, the reasons for this prioritization differed among individuals. These results suggest a diversity of relationships with the ecosystems. In addition to the productive or work relationships, the family, the community, and other aspects of well-being modulate the interactions between individuals and ecosystems. These results are consistent with those found by Hicks et al. (2015) and confirm the need to go beyond simplistic dichotomies between intrinsic and instrumental values (Tallis and Lubchenco 2014, Chan et al. 2016, Arias-Arevalo et al. 2017). Our results suggest that reasons of importance can be associated with intrinsic values, such as nature appreciation. They can also be associated with instrumental values, such as the work (that is, the activities) each individual performs to secure his economic support. But we also found that the prevalence of relational values, for example, the well-being of cattle, is derived from the relationship that the cattle rancher establishes with his animal, his assuming the responsibility for keeping it healthy and content. These meanings and emotions coexist with economic values related to livelihoods and production. The importance of water transcends the productive activity of individuals, since it is related to the support of life itself and goes beyond the present, affecting the well-being of future generations. These reasons express relationships of reciprocity and extend beyond the local and present context.

The study of reasons for the importance attributed to the prioritized services grounds the search for alternative paths toward sustainability and emphasizes the perspectives of a critical and vulnerable group of stakeholders in the tropics whose views are often ignored when public policies are designed. In the Mexican context, smallholders are most frequently unheard, even when they get organized to generate more visibility (Nuijten 2003, Paz-Salinas 2005). In the study region, a group of inhabitants got organized to participate in environmental policies and local rural development, but their efforts were ignored by the local authorities (Cano-Castellanos and Lazos-Chavero 2017). While successful cases can be documented where smallholders have had some influence in the application of environmental policies (see McAfee and Shapiro 2010), they remain exceptional. Generally, in Mexico, the claims and projects of rural producers are restricted by corporate and hierarchical structures (Nuijten 2003, Henderson 2017). Smallholders are key to maintaining ecosystem services that support biodiversity and food production. Indepth assessments of the narratives that clarify the links between smallholders and the ecosystem (Klain et al. 2014) should be the basis for the design and implementation of inclusive, legitimate, and flexible policies toward the construction of sustainability.

\section{Implications for sustainability: more flexible and inclusive policies}

Smallholders are key to food production and biodiversity conservation across the global south, and thus are crucial partners in the coconstruction of sustainable pathways. It has been proposed that in order to improve management and make more sustainable public policies, the voices of all stakeholders must be included and negotiated (Reed 2008). An inclusivity perspective emphasizes empowerment, equity, trust, and learning (Reed 2008, Chandra et al. 2017). The challenge is how to include local perspectives to advance in processes where communities lead the way forward. In Mexico, some success cases at the local level can inspire us in the construction of participatory processes with the communities (Bofill-Poch 2002, Bray et al. 2003). But we recognize that these processes, which involve dialogues and negotiations, still have difficulties associated with the transformations of power relations. Structural changes are necessary to achieve the inclusion of plurality at different scales - local and regional (Paz-Salinas 2005, Lazos- Chavero 2013). Flexible, heterogeneous policies that make the producers feel represented would promote greater adoption of the responsibility that implies having access to a benefit delivered by the government.

\section{CONCLUSIONS}

We found an important heterogeneity of services perceived by individuals within a single stakeholder group: smallholder cattle ranchers. The range of perceived services was strongly tied to cattle ranchers' livelihood and to the particularities of the ecosystem they inhabit. The views of smallholders complemented the view derived from categorizations of services structured by scientists. This study contributes to the growing literature on ecosystem service perceptions by emphasizing stakeholder group heterogeneity.

Priorities for different services were strongly biased by the productive activity of the stakeholder; for example, just as fishermen prioritize the provisioning services linked to fishing, their productive activity (Hicks et al. 2013), the cattle ranchers prioritized some provisioning services, such as pasture or those linked to livestock production. Although provisioning services prevailed among the priorities, we recognize the diversity of services perceived, and we specifically show that some cattle ranchers saw a connection between some ecosystem services. Also, 
priorities were modified by changes in livelihood associated with generation change linked to differences in opportunities and education. This generation change is particularly critical because most young smallholders emigrate, and the new generations of smallholders who are still managing the forest are key stakeholders in the management of socio-ecosystems.

Making visible the diversity of values associated with the importance of ecosystem services by smallholders whose lands host a significant portion of the world's biodiversity and who have been excluded or marginalized from decision-making processes (Apgar 2017) is critical for designing more legitimate policies toward environmental sustainability. Policies in which individuals feel represented in their priorities and values would promote greater adoption of these policies and could increase sharing responsibilities beyond simply receiving aid from the government. The documentation and rescue of local knowledge will empower these unheard stakeholders and facilitate their participation in the design of public policies.

Responses to this article can be read online at: http://www.ecologyandsociety.org/issues/responses. php/10457

\begin{abstract}
Acknowledgments:
Alejandra Tauro thanks the Postgraduate Programme in Biological Sciences (Programa de Posgrado en Ciencias Biológicas) of the National Autonomous University of Mexico (Universidad Nacional Autónoma de México [UNAM]) for support for her doctoral studies; also the National Council for Science and Technology (Consejo Nacional de Ciencia y Tecnología [CONACYT]) for a scholarship received for the doctoral research program. This article is a requirement for the degree of Doctor of Science. This work was done thanks to the UNAM-DGAPAPAPIIT Program through project IN211114, IN211417, SEPCONACyT 2015-255544. We are grateful to all cattle rancher that participated in this research. Alejandra Atzin Hernandez, Daniel Ferreyra, Romeo Saldaña, and Felipe Arreola assisted during the fieldwork. Adriana Flores-Diaz helped with land cover analysis for La Huerta municipality. Francisco Mora-Ardila and Sofia MonroySais provided important comments on this work. Ann Grant and Emily Wheeler improved the English revision. Three anonymous reviewers helped improve this manuscript.
\end{abstract}

\section{LITERATURE CITED}

Albizua, A. 2016. Social-ecological impacts of agrarian intensification: the case of modern irrigation in Navarre. Dissertation. Universitat Autonoma de Barcelona, Barcelona, Spain.

Almeida, E. 2012. Ejidatarias, posesionarias, avecindadas. Mujeres frente a sus derechos de propiedad en tierras ejidales de México. Estudios Agrarios, revista de la Procuraduría Agraria 18 (52):13-57.

Apgar, M. 2017. Biocultural approaches: opportunities for building more inclusive environmental governance. IDS Working Paper 502. IDS, Brighton. [online] URL: http://opendocs.ids.ac. uk/opendocs/handle/123456789/13381
Arias-Arévalo, P., B. Martín-López, and E. Gómez-Baggethun. 2017. Exploring intrinsic, instrumental, and relational values for sustainable management of social-ecological systems. Ecology and Society 22(4):43. http://dx.doi.org/10.5751/ES-09812-220443

Arreola-Villa, F. 2017. Educación ambiental en el medio rural: un estudio con jóvenes de preparatoria en la costa sur de Jalisco. Thesis. Universidad de Gualadajara, Jalisco, México.

Asah, S. T., A. D. Guerry, D. J. Blahna, and J. J. Lawler. 2014. Perception, acquisition and use of ecosystem services: human behavior, and ecosystem management and policy implications. Ecosystem Services 10:180-186. http://dx.doi.org/10.1016/j. ecoser.2014.08.003

Ayala-Berdon, J., J. E. Schondube, and K. E. Stoner. 2009. Seasonal intake responses in the nectar-feeding bat Glossophaga soricina. Journal of Comparative Physiology B 179(5):553-562. http://dx.doi.org/10.1007/s00360-008-0335-Z

Beilin, R. 2005. Photo-elicitation and the agricultural landscape: 'seeing' and 'telling' about farming, community and place. Visual Studies 20(1):56-68. http://dx.doi.org/10.1080/14725860500064904

Berbés-Blázquez, M. 2012. A participatory assessment of ecosystem services and human wellbeing in rural Costa Rica using photo-voice. Environmental Management 49(4):862-875. http:// dx.doi.org/10.1007/s00267-012-9822-9

Bofill-Poch, S. 2002. Organización forestal comunal y sustentabilidad en San Juan Nuevo (Michoacán): poder y conflicto en torno a los usos locales, nacionales e internacionales de la reciprocidad. Endoxa: Series Filosóficas 15:61-74. http://dx. doi.org/10.5944/endoxa.15.2002.5037

Bray, D. B., L. Merino-Pérez, P. Negreros-Castillo, G. SeguraWarnholtz, J. M. Torres-Rojo, and H. F. M. Vester. 2003. Mexico's community-managed forests as a global model for sustainable landscapes. Conservation Biology 17(3):672-677. http://dx.doi. org/10.1046/j.1523-1739.2003.01639.x

Bryman, A. 2006. Integrating quantitative and qualitative research: how is it done? Qualitative Research 6(1):97-113. http:// dx.doi.org/10.1177/1468794106058877

Cáceres, D. M., E. Tapella, F. Quétier, and S. Díaz. 2015. The social value of biodiversity and ecosystem services from the perspectives of different actors. Ecology and Society 20(1):62. http://dx.doi.org/10.5751/ES-07297-200162

Camps-Calvet, M., J. Langemeyer, L. Calvet-Mir, and E. GómezBaggethun. 2016. Ecosystem services provided by urban gardens in Barcelona, Spain: insights for policy and planning. Environmental Science \& Policy 62:14-23. http://dx.doi. org/10.1016/j.envsci.2016.01.007

Cano-Castellanos, I. J., and E. Lazos-Chavero. 2017. Política pública y acciones ambientales en la Costa Sur de Jalisco. Revista Mexicana de Sociología 79(1):93-122. http://dx.doi.org/10.22201/ iis.01882503p.2017.1.57654

Castillo, A., C. Godínez, N. Schroeder, C. Galicia, A. PujadasBotey, and L. Martínez. 2009. El bosque tropical seco en riesgo: conflictos entre uso agropecuario, desarrollo turístico y provisión de servicios ecosistémicos en la Costa de Jalisco, México. Interciencia 34(12):844-850. [online] URL: http://www.redalyc. org/pdf/339/33913151002.pdf 
Castillo, A., A. Magaña, A. Pujadas, L. Martínez, and C. Godínez. 2005. Understanding the interaction of rural people with ecosystems: a case study in a tropical dry forest of Mexico. Ecosystems 8(6):630-643. http://dx.doi.org/10.1007/s10021-005-0127-1

Castro, A. J., B. Martín-López, M. García-LLorente, P. A. Aguilera, E. López, and J. Cabello. 2011. Social preferences regarding the delivery of ecosystem services in a semiarid Mediterranean region. Journal of Arid Environments 75 (11):1201-1208. http://dx.doi.org/10.1016/j.jaridenv.2011.05.013

Chan, K. M. A., P. Balvanera, K. Benessaiah, M. Chapman, S. Díaz, E. Gómez-Baggethun, R. Gould, N. Hannahs, K. Jax, S. Klain, G. W. Luck, B. Martín-López, B. Muraca, B. Norton, K. Ott, U. Pascual, T. Satterfield, M. Tadaki, J. Taggart, and N. Turner. 2016. Opinion: Why protect nature? Rethinking values and the environment. Proceedings of the National Academy of Sciences of the United States of America 113(6):1462-1465. http:// dx.doi.org/10.1073/pnas.1525002113

Chandra, A., K. E. Mcnamara, and P. Dargusch. 2017. The relevance of political ecology perspectives for smallholder climate-smart agriculture: a review. Journal of Political Ecology 24:820-842. http://dx.doi.org/10.2458/v24i1.20969

Chauvet, M. 2001. Los nuevos retos de la ganadería. Pages 227-232 in L. Hernández, editor. Historia ambiental de la ganadería en México. Institut Recherche Développement, Instituto de Ecología A. C., Xalapa, Veracruz, México.

Cohen-Salgado, D. 2014. Estrategias de manejo del bosque tropical seco: un estudio de caso en Jalisco. Thesis. Universidad Nacional Autónoma de México, Morelia, Michoacán, México.

Comunidad de Estados Latinoamericanos y Caribeños (CELAC). 2014. Plan para la seguridad alimentaria, nutrición y erradicación del hambre 2025. FAO, CEPAL, ALADI, Santiago, Chile.

Cordero-Cueva, P. 2005. Percepciones sociales sobre el deterioro ambiental y la restauración ecológica: un estudio de caso en la región de Chamela-Cuixmala Jalisco. Thesis. Universidad Nacional Autónoma de México, Morelia, Michoacán, México.

Danley, B., and C. Widmark. 2016. Evaluating conceptual definitions of ecosystem services and their implications. Ecological Economics 126:132-138. http://dx.doi.org/10.1016/j. ecolecon.2016.04.003

Daw, T., K. Brown, S. Rosendo, and R. Pomeroy. 2011. Applying the ecosystem services concept to poverty alleviation: the need to disaggregate human well-being. Environmental Conservation 38 (4):370-379. http://dx.doi.org/10.1017/S0376892911000506

Díaz, S., U. Pascual, M. Stenseke, B. Martín-López, R. T. Watson, Z. Molnár, R. Hill, K. M. A. Chan, I. A. Baste, K. A. Brauman, S. Polasky, A. Church, M. Lonsdale, A. Larigauderie, P. W. Leadley, A. P. E. van Oudenhoven, F. van der Plaat, M. Schröter, S. Lavorel, Y. Aumeeruddy-Thomas, E. Bukvareva, K. Davies, S. Demissew, G. Erpul, P. Failler, C. A. Guerra, C. L. Hewitt, H. Keune, S. Lindley, and Y. Shirayama. 2018. Assessing nature's contributions to people. Science 359(6373):270-272. http://dx.doi. org/10.1126/science.aap8826

Driscoll, D. L., A. Appiah-Yeboah, P. Salib, and D. J. Rupert. 2007. Merging qualitative and quantitative data in mixed methods research: how to and why not. Ecological and Environmental Anthropology 3(1):18-28. [online] URL: http://digitalcommons. unl.edu/icwdmeea/18/

Durand, L., and E. Lazos. 2004. Colonization and tropical deforestation in the Sierra Santa Marta, Southern Mexico. Environmental Conservation 31(1):11-21. http://dx.doi.org/10.1017/ $\underline{\mathrm{S} 0376892904001006}$

Faugier, J., and M. Sargeant. 1997. Sampling hard to reach populations. Journal of Advanced Nursing 26:790-797. http://dx. doi.org/10.1046/j.1365-2648.1997.00371.X

Fisher, B., R. K. Turner, and P. Morling. 2009. Defining and classifying ecosystem services for decision making. Ecological Economics 68(3):643-653. http://dx.doi.org/10.1016/j. ecolecon.2008.09.014

Flores-Díaz, A. C. 2015. Manejo de la zona riparia de la cuenca del río Cuitzmala, Jalisco. Dissertation. Instituto de Ecología, A. C., Xalapa, Veracruz, México.

Food and Agriculture Organization of the United Mations (FAO). 2014. Agricultura familiar en América Latina y el Caribe: recomendaciones de política. Santiago, Chile.

García, A., M. Valtierra-Azotla, and B. C. Lister. 2010. Behavioral responses to seasonality by two Sceloporine lizard species from a tropical dry forest. Animal Biology 60(1):97-113. http://dx.doi.org/10.1163/157075610X12610595764291

García-Oliva, F., A. Camou, and J. M. Maass. 2002. El clima de la región central de la costa del Pacífico Mexicano. Pages 3-10 in F. A. Noguera, J. H. Vega, A. N. García-Aldrete, and M. Quesada, editors. Historia Natural de Chamela. Instituto de Biología, UNAM, México, D. F., México.

Garrido, P., M. Elbakidze, P. Angelstam, T. Plieninger, F. Pulido, and G. Moreno. 2017. Stakeholder perspectives of wood-pasture ecosystem services: a case study from Iberian dehesas. Land Use Policy 60:324-333. http://dx.doi.org/10.1016/j.landusepol.2016.10.022

Gerritsen, P., and J. D. van der Ploeg. 2006. Dinámica espacial y temporal de la ganadería extensiva: estudio de caso de la Sierra de Manantlán en la costa sur de Jalisco. Relaciones. Estudios de historia y sociedad XXVII:165-191. [online] URL: http://www. redalyc.org/articulo.oa?id $=13710808$

Gibbs, G. 2012. El análisis de datos en investigación cualitativa. Ediciones Morata, Madrid, Spain.

Godínez-Contreras, M. del C. 2003. Percepciones del sector turismo sobre el ambiente, los servicios ecosistémicos y las instituciones relacionadas con la conservación del ecosistema de selva baja caducifolia en la costa sur de Jalisco. Thesis. Universidad Nacional Autónoma de México, Morelia, Michoacán, México.

Gómez-Bonilla, A. 2006. Las percepciones sociales de las mujeres sobre los servicios ecosistémicos de dos comunidades de la región de Chamela, Jalisco. Thesis. Universidad Nacional Autónoma de México, Morelia, Michoacán, México.

Haida, C., J. Rüdisser, and U. Tappeiner. 2016. Ecosystem services in mountain regions: experts' perceptions and research intensity. Regional Environmental Change 16:1989-2004. http://dx.doi. org/10.1007/s10113-015-0759-4 
Haines-Young, R., and M. Potschin. 2013. Common International Classification of Ecosystem Services (CICES): consultation on Version 4, August-December 2012. Report to the European Environmental Agency, Nottingham, London, UK.

Harper, D. 2002. Talking about pictures: a case for photo elicitation. Visual Studies 17(1):13-26. http://dx.doi. org/10.1080/1472586022013734

Henderson, T. P. 2017. State-peasant movement relations and the politics of food sovereignty in Mexico and Ecuador. Journal of Peasant Studies 44(1):33-55. http://dx.doi.org/10.1080/03066150.2016 .1236024

Heras, M., J. D. Tabara, and A. Meza. 2016. Performing biospheric futures with younger generations: a case in the MAB Reserve of La Sepultura, Mexico. Ecology and Society 21(2):14. http://dx.doi.org/10.5751/ES-08317-210214

Hicks, C. C., J. E. Cinner, N. Stoeckl, and T. R. McClanahan. 2015. Linking ecosystem services and human-values theory. Conservation Biology 29(5):1471-1480. http://dx.doi.org/10.1111/ cobi. 12550

Hicks, C. C., N. A. J. Graham, and J. E. Cinner. 2013. Synergies and tradeoffs in how managers, scientists, and fishers value coral reef ecosystem services. Global Environmental Change 23 (6):1444-1453. http://dx.doi.org/10.1016/j.gloenvcha.2013.07.028

Iniesta-Arandia, I., M. García-Llorente, P. A. Aguilera, C. Montes, and B. Martín-López. 2014. Socio-cultural valuation of ecosystem services: uncovering the links between values, drivers of change, and human well-being. Ecological Economics 108:36-48. http://dx.doi.org/10.1016/j.ecolecon.2014.09.028

Instituto Nacional de Estadística y Geografía (INEGI). 2009. Prontuario de información geográfica municipal de los Estados Unidos Mexicanos. La Huerta, Jalisco. D.F., México.

Instituto Nacional de Estadística y Geografía (INEGI). 2010. Censo de Población y Vivienda 2010. México. D.F., México.

Instituto Nacional de Estadística y Geografía (INEGI). 2015. Carta digital de uso del suelo y vegetación 1: 250 000. Municipio La Huerta, Jalisco, México. D.F., México. [online] URL: http:// www.inegi.org. $\mathrm{mx} / \mathrm{geo} / \mathrm{contenidos/recnat/usosuelo/}$

International Fund for Agricultural Development and United Nations Environment Program (IFAD-UNEP). 2013. Smallholders, food security, and the environment. Rome, Italy. [online] URL: http://wedocs.unep.org/handle/20.500.11822/8127

Jacobs, S., N. Dendoncker, B. Martín-López, D. N. Barton, E. Gomez-Baggethun, F. Boeraeve, F. L. McGrath, K. Vierikko, D. Geneletti, K. J. Sevecke, N. Pipart, E. Primmer, P. Mederly, S. Schmidt, A. Aragão, H. Baral, R. H. Bark, T. Briceno, D. Brogna, P. Cabral, R. De Vreese, C. Liquete, H. Mueller, K. S. H. Peh, A. Phelan, A. R. Rincón, S. H. Rogers, F. Turkelboom, W. Van Reeth, B. T. van Zanten, H. K. Wam, and C. L. Washbourn. 2016. A new valuation school: integrating diverse values of nature in resource and land use decisions. Ecosystem Services 22:213-220. http://dx. doi.org/10.1016/j.ecoser.2016.11.007

Klain, S. C., T. A. Satterfield, and K. M. A. Chan. 2014. What matters and why? Ecosystem services and their bundled qualities. Ecological Economics 107:310-320. http://dx.doi.org/10.1016/j. ecolecon.2014.09.003
Lau, J. D., C. C. Hicks, G. G. Gurney, and J. E. Cinner. 2018. Disaggregating ecosystem service values and priorities by wealth, age, and education. Ecosystem Services 29:91-98. http://dx.doi. org/10.1016/j.ecoser.2017.12.005

Lazos-Chavero, E. 1996. El encuentro de subjetividades en la ganadería campesina. Ciencias 44:36-45. [online] URL: http:// www.ejournal.unam.mx/cns/no44/CNS04406.pdf

Lazos-Chavero, E. 2013. Interculturalidad: naturalezas dominadas, naturalezas vividas. Pages 299-314 in S. E. Hernández-Loeza, M. I. Ramírez-Duque, Y. ManjarrezMartínez, and A. Flores-Rosas, editors. Educación Intercultural a Nivel Superior. Reflexiones desde diversas realidades latinoamericanas. UIEP, UCI- RED, UPEL, Puebla, México.

Lazos-Chavero, E., J. Zinda, A. Bennett-Curry, P. Balvanera, G. Bloomfield, C. Lindell, and C. Negra. 2016. Stakeholders and tropical reforestation: challenges, trade-offs, and strategies in dynamic environments. Biotropica 48(6):900-914. http://dx.doi. org/10.1111/btp.12391

Lê, S., J. Josse, and F. Husson. 2008. FactoMineR: an R package for multivariate analysis. Journal of Statistical Software 25 (1):1-18. http://dx.doi.org/10.18637/jss.v025.i01

Long, N. 2001. Development sociology. Actor perspectives. Routledge, London and New York.

Maass, M., P. Balvanera, P. Bourgeron, M. Equihua, J. Baudry, J. Dick, M. Forsius, L. Halada, K. Krauze, M. Nakaoka, D. E. Orenstein, T. W. Parr, C. L. Redman, R. Rozzi, M. Santos-Reis, A. M. Swemmer, and A. Vădineanu. 2016. Changes in biodiversity and trade-offs among ecosystem services, stakeholders, and components of well-being: the contribution of the International Long-Term Ecological Research network (ILTER) to Programme on Ecosystem Change and Society (PECS). Ecology and Society 21(3):31. http://dx.doi.org/10.5751/ES-08587-210331

Maass, J. M., P. Balvanera, A. Castillo, G. C. Daily, H. A. Mooney, P. Ehrlich, M. Quesada, A. Miranda, V. J. Jaramillo, F. GarcíaOliva, A. Martínez-Yrizar, H. Cotler, J. López-Blanco, A. PérezJiménez, A. Búrquez, C. Tinoco, G. Ceballos, L. Barraza, and R. Ayala. 2005. Ecosystem services of tropical dry forests: insights from long- term ecological and social research on the Pacific Coast of Mexico. Ecology and Society 10(1):17. http://dx.doi. org/10.5751/ES-01219-100117

Mahajan, S. L., and T. Daw. 2016. Perceptions of ecosystem services and benefits to human wellbeing from community-based marine protected areas in Kenya. Marine Policy 74:108-119. http://dx.doi.org/10.1016/j.marpol.2016.09.005

Martínez-Hernández, L. 2003. Percepciones sociales sobre los servicios ecosistémicos en dos comunidades aledañas a la Reserva de la Biosfera Chamela-Cuixmala, Jalisco. Thesis. Universidad Michoacana de San Nicolás de Hidalgo, Morelia, Michoacán, Mexico.

McAfee, K., and E. N. Shapiro. 2010. Payments for ecosystem services in Mexico: nature, neoliberalism, social movements, and the state. Annals of the Association of American Geographers 100 (3):579-599. http://dx.doi.org/10.1080/00045601003794833

Mendoza-Varela, E. L. 2010. Conocimientos, percepciones y actitudes ambientales de jóvenes de bachillerato de dos comunidades 
aledañas a la Reserva de la Biosfera Chamela-Cuixmala. Thesis. Universidad Nacional Autónoma de México, Morelia, Michoacán, México.

Millenium Ecosystem Assessment (MEA). 2005. Ecosystems and human well-being. Synthesis. Island Press, Washington, D.C., USA.

Mills, J., A. Bonner, and K. Francis. 2006. Adopting a constructivist approach to grounded theory: implications for research design. International Journal of Nursing Practice 12 (1):8-13. http://dx.doi.org/10.1111/j.1440-172X.2006.00543.x

Monroy-Sais, S. 2013. Historia, uso y manejo de los bosques en un ejido de la región Chamela-Cuixmala, Jalisco. Thesis. Universidad Nacional Autónoma de México, Morelia, Michoacán, México.

Montes de Oca-Barrera, L. B. 2016. Una ventana epistémica a la (inter) subjetividad. Las potencialidades del método etnográfico. Forum: qualitative social research. Sozialforschung 17(1):8. [online] URL: http://www.qualitative-research.net/index.php/ fqs/article/view/2227

Naime-Sánchez, J. del C. 2016. Valoración económica de cuatro servicios ecosistémicos en la región de Chamela, Jalisco, México. Thesis. Universidad Nacional Autónoma de México, Morelia, Michoacán, México.

Nawrotzki, R., F. Riosmena, and L. Hunter. 2013. Do rainfall deficits predict U.S.-bound migration from rural Mexico? Evidence from the Mexican census. Population Research and Policy Review 32(1):129-158. http://dx.doi.org/10.1007/s11113-012-9251-8

Nuijten, M. 2003. Power, community and the state: the political anthropology of organisation in Mexico. Pluto Press, London, UK. http://dx.doi.org/10.2307/j.ctt18dzv4z

Oksanen, J., F. Guillaume Blanchet, M. Friendly, R. Kindt, P. Legendre, D. McGlinn, P. R. Minchin, R. B. O'Hara, G. L. Simpson, P. Solymos, M. H. H. Stevens, E. Szoecs, and H. Wagner. 2008. vegan: community ecology package. R package version 2.0-9. R Foundation for Statistical Computing, Vienna, Austria. [online] URL: http://CRAN.R-project.org/package=vegan

Pascual, U., P. Balvanera, S. Diaz, G. Pataki, E. Roth, M. Stenseke, R. Watson, E. Dessane, S. Breslow, M. Islar, E. Kelemen, H. Keune, V. Maris, W. Pengue, M. Quaas, S. Subramanian, H. Wittmer, A. Mohamed, Y. Al-Hafedh, S. Asah, P. Berry, E. Bilgin, C. Bullock, D. Cáceres, C. Golden, E. Gómez-Baggethun, D. González-Jiménez, J. Houdet, R. Kumar, P. May, A. Mead, P. O'Farrell, D. Pacheco-Balanza, R. Pandit, R. Pichis-Madruga, F. Popa, S. Preston, H. Saarikoski, B. Strassburg, M. Verma, N. Yagi, S. Ahn, E. Amankwah, H. Daly-Hassen, E. Figueroa, K. Ma, M. van den Belt, and F. Wickson. 2017. Valuing nature's contributions to people: the IPBES approach. Current Opinion in Environmental Sustainability 26-27:7-16. http://dx.doi.org/10.1016/ j.cosust.2016.12.006

Paz-Salinas, M. F. 2005. La participación en el manejo de las áreas naturales protegidas. Actores e intereses en conflicto en el Corredor Biológico Chichinautzin, Morelos. CRIM-UNAM, CuernavacaMorelos, Mexico.

Perez-Escobedo, H. M. 2011. Necesidades de información para el manejo de los socio-ecosistemas en la región Chamela-Cuixmala,
Jalisco. Thesis. Universidad Nacional Autónoma de México, Morelia, Michoacán, México.

R Development Core Team. 2015. R: a language and environment for statistical computing. R Foundation for Statistical Computing, Vienna, Austria. [online] URL: http://www.R-project.org/

Reed, M. S. 2008. Stakeholder participation for environmental management: a literature review. Biological Conservation 141 (10):2417-2431. http://dx.doi.org/10.1016/j.biocon.2008.07.014

Registro Agrario Nacional (RAN). 2016. Padrón e historial de núcleos agrarios. Registro Agrario Nacional. México, D.F., México. [online] URL: http://www.ran.gob.mx/ran/index.php/ sistemas-de-consulta/phina

Revel-Mouroz, J. 1972. Aprovechamiento y colonización del trópico húmedo mexicano: la vertiente del Golfo y del Caribe. Fondo de Cultura Económica, DF, Mexico.

Rodríguez, D. I., G. Anríquez, and J. L. Riveros. 2016. Food security and livestock: the case of Latin America and the Caribbean. Ciencia e Investigación Agraria 43(1):5-15. http://dx. doi.org/10.4067/S0718-16202016000100001

Salas-Quintanal, H., and Í. González-de la Fuente. 2014. The reproduction of the labor pluri-activity among rural young people in Tlaxcala, Mexico. Papeles de Población 20(79):281-307. [online] URL: http://www.redalyc.org/pdf/112/11230198010.pdf

Saldaña-Espejel, A. 2008. Prioridades de restauración para la recuperación de servicios ecosistémicos asociados a los aspectos hidrológicos de la cuenca del rio Cuiztmala, en el Pacífico Mexicano. Thesis. Universidad Nacional Autónoma de México, Morelia, Michoacán, México.

Sánchez-Azofeifa, G. A., M. Quesada, P. Cuevas-Reyes, A. Castillo, and G. Sánchez-Montoya. 2009. Land cover and conservation in the area of influence of the Chamela-Cuixmala Biosphere Reserve, Mexico. Forest Ecology and Management 258 (6):907-912. http://dx.doi.org/10.1016/j.foreco.2008.10.030

Sanchez-Matías, M. 2010. Los beneficios del monte: percepción social y consumo de los servicios ecosistémicos derivados de la diversidad vegetal en la cuenca del rio Cuitzmala, Jalisco. Thesis. Universidad Nacional Autónoma de México, Morelia, Michoacán, México.

Schroeder, N. M., and A. Castillo. 2013. Collective action in the management of a tropical dry forest ecosystem: effects of Mexico's property rights regime. Environmental Management 51 (4):850-861. http://dx.doi.org/10.1007/s00267-012-9980-9

Secretaría de Agricultura Ganadería Desarrollo Rural Pesca y Alimentación (SAGARPA). 2016. Padrón de beneficiarios PROGAN 2014. Jalisco. México, D.F., México. [online] URL: http://www.sagarpa.gob.mx/ganaderia/Paginas/beneficiariosPROGAN-2014.aspx

Sherren, K., J. Fischer, and R. Price. 2010. Using photography to elicit grazier values and management practices relating to tree survival and recruitment. Land Use Policy 27(4):1056-1067. http:// dx.doi.org/10.1016/j.landusepol.2010.02.002

Solórzano-Murillo, L. S. 2008. Percepciones sobre servicios ecosistémicos relacionados con el agua en comunidades rurales de 
la cuenca del rio Cuitzmala, Jalisco. Thesis. Universidad Nacional Autónoma de México, Morelia, Michoacán, México.

Tallis, H., and J. Lubchenco. 2014. Working together: a call for inclusive conservation. Nature 515(7525):27-28. http://dx.doi. org/10.1038/515027a

The Economics of Ecosystems and Biodiversity (TEEB). 2010. The Economics of Ecosystems and Biodiversity Ecological and Economic Foundations. Earthscan, London and Washington. [online] URL: http://www.teebweb.org/our-publications/teebstudy-reports/ecological-and-economic-foundations/

Tickle-Degnen, L., and R. Rosenthal. 1990. The nature of rapport and its nonverbal correlates. Psychological Inquiry 1(4):285-293. http://dx.doi.org/10.1207/s15327965pli0104 1

Torales-Ayala, G. de J. 2015. La relación ambiente - cultura en una sociedad ranchera ante el proceso de ganaderización: San Miguel, Villa Purificación, Jalisco. Thesis. Escuela Nacional de Antropología e Historia, Ciudad de México, México.

Trilleras-Motha, J. M. 2008. Análisis socio-ecológico del manejo, degradación y restauración del bosque tropical seco de la región de Chamela-Cuixmala, México. Thesis. Universidad Nacional Autónoma de México, Morelia, Michoacán, México.

Ugartechea-Salmerón, O. A. 2015. Valor económico y disyuntivas ambientales en el manejo del bosque tropical seco en Chamela, Jalisco. Thesis. Universidad Nacional Autónoma de México, Morelia, Michoacán, México.

Vázquez-García, V. 2015. Aging ejidos in the wake of neo-liberal reform: livelihood predicaments of Mexican ejidatarias. Pages 169-183 in C. S. Archambault and A. Zoomers, editors. Global trends in land tenure reform: gender impacts. Routledge, London, UK.

Warman, A. 2003. Mexican land reform: a long-term perspective. Land Reform. Land Settlement and Cooperatives 2:84-95. [online] URL: http://www.fao.org/docrep/006/j0415t/j0415t09.htm

Wieland, R., S. Ravensbergen, E. J. Gregr, T. Satterfield, and K. M. A. Chan. 2016. Debunking trickle-down ecosystem services: the fallacy of omnipotent, homogeneous beneficiaries. Ecological Economics 121:175-180. http://dx.doi.org/10.1016/j.ecolecon.2015.11.007

Yahdjian, M. L., O. E. Sala, and K. M. Havstad. 2015. Rangeland ecosystem services: shifting focus from supply to reconciling supply and demand. Frontiers in Ecology and the Environment 13 (1):44-51. http://dx.doi.org/10.1890/140156 
Appendix 1. Photographs and ecosystem services drawings

\section{1 - Photographs descriptions}

We used 12 photographs showing different types of land use for the tropical dry forest of the region to identify ecosystem services (benefits [Fig. A1.1]). The photos were captured by different colleagues working in the study area (see below Table A1.1). All images were selected to emphasize the cattle ranchers' activity (Table A1.1). They were shown in a random order to the interviewees. We used an identifier number on each photograph to match the notes taken in the interviews.

Here, we used the photographs as visual depictions of the landscape to stimulate interviewees to identify ecosystem services. At the same time, the images evoked subjects' memories and life experiences in the region. With the photographs, we wanted to motivate the cattle ranchers to recognize services that exist at different temporal moments, taking into account for the seasonality of the study ecosystem.

Fig. A1.1. Sample of photos used (see Table A1.1 for descriptions)
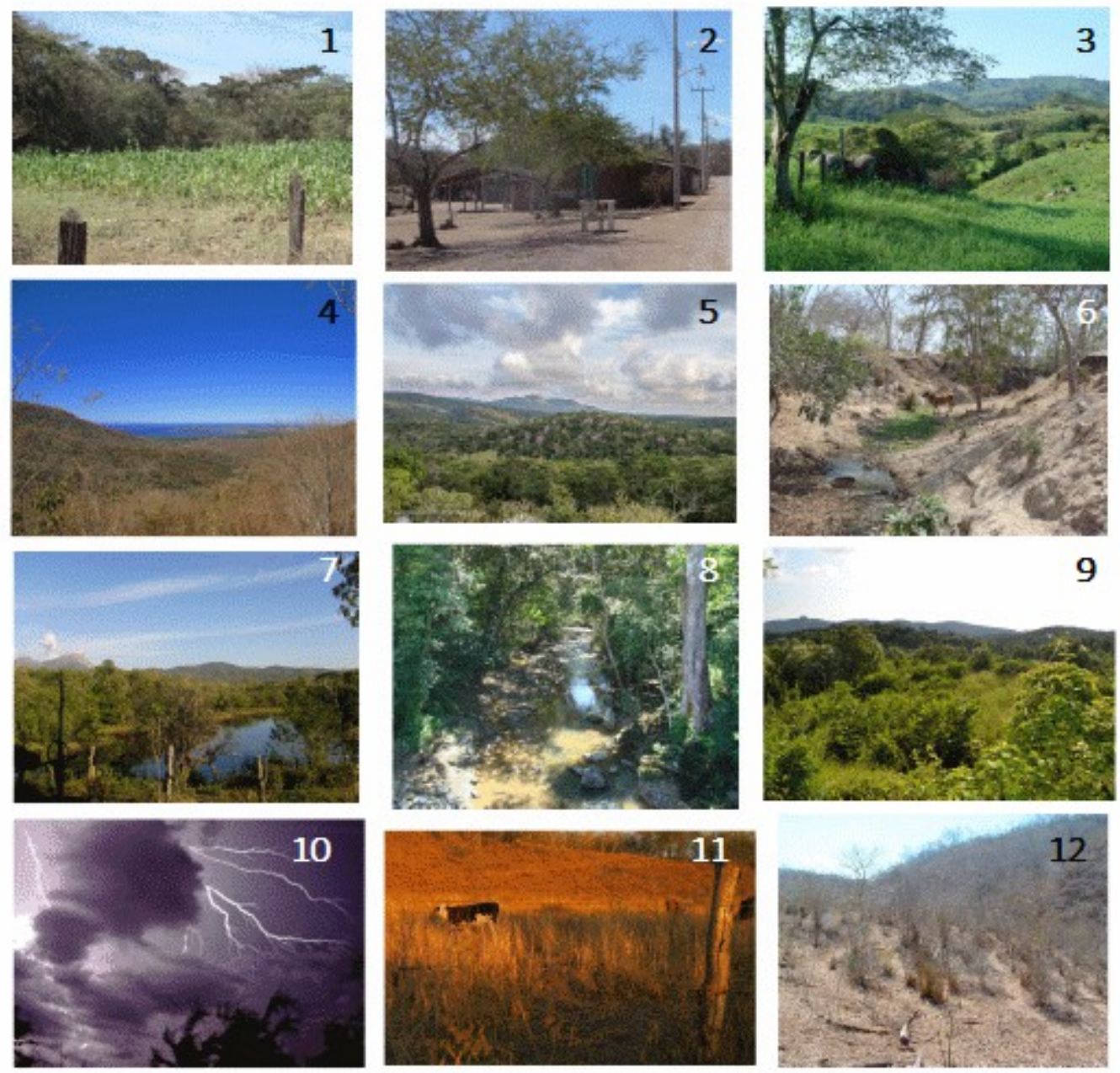
Table A1.1. Description of each picture used during the interviews

\begin{tabular}{ll}
\hline \hline Photograph & Description. This picture shows... \\
\hline 1 & ...a corn crop from a moist area (in rainy season, no irrigation is required) \\
2 & ...the shadows of trees in a typical town in the study area \\
3 & ...a plot with shadows of trees and pasture for livestock \\
4 & ...the sea and tropical dry forest from a plot in the study area \\
5 & ...a panoramic view of tropical dry forest from the UNAM's Biology Station \\
6 & ...a paddock with a "water eye" (water for livestock) and signs of soil erosion \\
7 & ...a dam in a plot intended to capture water from rain \\
8 & ...a stream below tropical dry forest cover \\
9 & ...an "abandoned" plot (without rancher activity) where the regeneration of a \\
10 & young secondary forest can be observed ("barbecho") \\
11 & ...a storm in the study region \\
12 & ...cattle and pasture in a paddock \\
\hline
\end{tabular}

Photographers:

1, 2, 3 and 6, Manuel Maass

4 and 12, Laboratorio de Biodiversidad y bienestar humano, IIES-UNAM

5, Leonor Solis

7 and 11, Oscar Salmeron

8, Adriana Flores, Manuel Maass, Adriana Saldaña

9, Julia Naime

10, Adolfo Montes

\section{2- Drawings and ecosystem services. Details about the ranking and importance interviews}

At the beginning of the interviews, we had 17 drawings on cards (examples in Fig. A1.2), and an additional 22 drawings were made during the interview by the team of interviewers. Each of the drawings represented an ecosystem service (benefits, Table 1). However, only 15 ecosystem services could be identified in the drawings we had with us (for example, see card 7 in Table 1). We wrote the name of the service on the drawing.

Some ecosystem services had abstract features that were difficult to draw; for these services, the interviewee had to associate the perceived benefit with a concrete image that would facilitate its representation in the drawing. This benefit was then clarified in writing on the card. For example, benefits such as "oxygen" or "clean air" were perceived in photos with vegetation (see pictures 5 and 8 in Fig. A1.1). As we dug deeper into these benefits, some individuals claimed that trees were needed "for oxygen" and also related the benefit to the forest, where "the air is better, cleaner" compared to the air in the towns or the city. These benefits were then represented indirectly through a tree, or as a 
continuous vegetation cover (that is, as a jungle).

When a drawing was associated with more than one service, all of the services were written on the card. For example, drawing 7 (Fig. A1.2, Table A1.2) was associated with the following ecosystem services: "Aesthetic appreciation of nature and the landscape, Habitat, Protection of Nature, Life, Water for life (wild)". Some interviewees wanted all these services together to be represented in the same drawing. In these cases, "packages" of services were defined.

Another situation that involved "service packages" was encountered during the hierarchical analysis. Some respondents selected a group of cards to designate "the most important" ecosystem service. Five interviewees combined between 2 to 8 ecosystem services under the number 1 ranking. We tried to identify with the interviewee which the service from the group had the greatest importance. When this was not possible, these services were grouped as "packages".

Fig. A1.2. Panel showing the nine most important ecosystem services cards drawn from the total cards used in the interview.

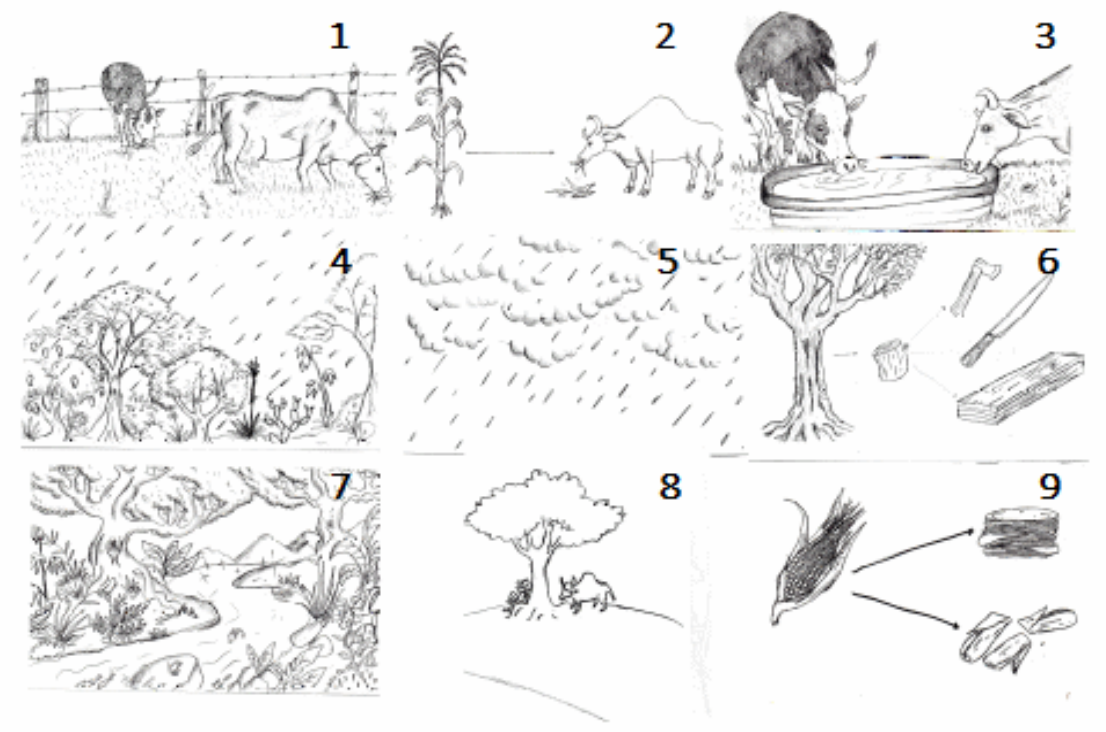

Table A1.2. Drawings of the most important ecosystem services (see all ecosystem services in Table 1) perceived from the photographs (Fig. A1.2).

\begin{tabular}{ll}
\hline Draw & Ecosystem services \\
\hline 1 & Pasture for livestock \\
2 & Cultivated fodder \\
3 & Water for livestock \\
4 & Forest-rain interaction (local people say, "the forest calls the water")
\end{tabular}




\begin{tabular}{ll}
5 & Rain \\
6 & Wood \\
7 & Aesthetic appreciation of nature and the landscape, Habitat, Protection of \\
& nature, "Life", Water for life (wild) \\
8 & Shade \\
9 & Food derived from maize \\
\hline
\end{tabular}

Cartoonist: Daniel Ferreyra García 
Appendix 2. Variables characterizing the livelihood of each cattle rancher

We studied 11 variables (Table A2.1) in a closed questionnaire to characterize the livelihoods of the cattle ranchers. The variables addressed basic information for each interviewee, such as age, education, place of work and residence. Other questions focused on the economic capital of each cattle rancher (for example, the number of cattle owned), if he had sons who contributed to work on the plot, or if he needed to hire labor.

We also explored the cattle ranchers' production strategies. Although each cattle rancher focused his activity on livestock, many individuals, for different reasons, also worked in other productive activities to improve family income. To understand more broadly their way of life, we asked about the economic or social support received, as well as if they received any kind of remittances from abroad. This was especially important for the profiles of cattle ranchers over 65 years of age, who worked partially in their productive activities with the help of their sons or a "cowboy".

Finally, we explored the relationship with the biological station and the academics to evaluate the role of possible biases associated with the history of the connection between the local townspeople and the UNAM academics, especially the biologists.

Table A2.1. Indicators and variables analyzed to characterize the livelihood of the cattle ranchers. The description of each variable shows the value that it would have if it was quantitative or categorical. The levels of the categorical variables were assigned following the assumptions underlying the definition of the indicator.

\begin{tabular}{lll}
\hline Indicator and definition & Variable & Description \\
\hline $\begin{array}{l}\text { Age structure } \\
\begin{array}{l}\text { Term used as a numerical value and also } \\
\text { to be included in the multivariate analysis } \\
\text { with qualitative data. The cut was made at }\end{array}\end{array}$ & 1- Age & $\begin{array}{l}\text { Years completed at the time of } \\
\text { the interview }\end{array}$ \\
$\begin{array}{l}\text { 65 years according to the definition of life } \\
\text { stages during the psycho-biological } \\
\text { development of the human being. }\end{array}$ & $\begin{array}{l}\text { "Minor" at } 65 \text { years old } \\
\text { "Older" at } 65 \text { years old }\end{array}$ \\
$\begin{array}{l}\text { Education Level } \\
\begin{array}{l}\text { Attendance, or not, at school and years of } \\
\text { education in school. Some did not attend } \\
\text { school or completed only the first years of } \\
\text { primary school. Others completed primary } \\
\text { school and higher levels of education. }\end{array}\end{array}$ & 2-Education \\
$\begin{array}{l}\text { Place of work and residence } \\
\begin{array}{l}\text { In cases where the interviewees lived } \\
\text { outside the ejido where they had their } \\
\text { plots of work, it was assumed that greater }\end{array}\end{array}$ & $\begin{array}{l}\text { None-Incomplete }=0 \\
\text { Basic-Superior }=1\end{array}$ \\
\end{tabular}


economic capital was required, especially for moving (which required gasoline) from their home to the working plot. There were those who travel few kilometers by foot or by horse), and other travel from 10 to $30 \mathrm{~km}$.

\section{Home's arrangement as a way to organize work}

The way the home is organized affects how work is organized. Having the help of sons (and daughters) in productive work involves the integration of family and work. The term defines a livelihood and clarifies the role of the family in the rural work.

\section{Financial capital}

Term suggests a specific management strategy linked to the cattle rancher's livelihood. Having enough capital enabled the cattle rancher to maintain or invest in extending and improving his productive activity. Livestock owners with low capital needed to expand their productive activities or to be employed in other jobs. In these cases, having cows became a "source of savings".

\section{Productive strategy $=$ diversity of productive activities}

Although the cattle rancher focused his activity on livestock, many people in the region also engaged in other productive activities. For example: day laborer, mason, farmer, merchant, technical adviser. When there was a low number of livestock, a more diverse productive activity improved family income.

\section{Economics support received}

Economic support can come from the federal government and it can be of a productive or social type. Productive programs are for livestock or for titles).

4- Lived in the $\mathrm{No}=0$

same place as $\quad$ Yes $=1$

the ejidatario

5- Sons who $\quad$ None $=0$

helped to work $\quad$ Some $=1$

the plot $\begin{array}{ll}\text { 8- Another } & \text { No }=0 \\ \text { productive } & \text { Yes }=1\end{array}$

activity (besides

cattle raising)

$\begin{array}{ll}\text { 9- } \text { Type of } & \text { None }=0 \\ \text { support } & \text { Social }=1 \\ \text { programs } & \text { Productive }=2 \\ & \text { Productive-Social }=3\end{array}$


cultivation. Social programs are for people

older than 70 years. People with children

abroad often received remittances that

10- Remittances $\quad$ No $=0$

Yes $=1$

support family income.

\section{Relation distance with the biologists} and the Biological Station (BS)

The BS was established in the area about

40 years ago and since then has had an

impact on the ecological management of

the region. About 10 years ago, the station

11- A

combination of

variables

qualitatively

established a

"distance"

relationship

with biologists
Distant $=1$

Medium $=2$

Close $=3$

Distant, if he had not participated in any research prior to this, but if he knew the BS.

Medium, if he had participated in other investigations prior to this, and if he knew, or not, the BS.

Close, if in addition to having participated in some research and knew the BS, he had also worked (or has a family member that worked or works) in the BS. 
Appendix 3. Ecosystem services coding and importance value index

\section{1- Criteria for coding benefits in ecosystem services}

In the field, we assigned correspondences between the benefits perceived in the photos and the cards drawn to perform the hierarchy. Then, during laboratory work, we systematically coded the services from the benefits to analyze the data. The expressions used by cattle ranchers to refer to the benefits were interpreted in the context of each full interview. The different expressions for the same service, as shown in Table 1, were considered synonyms for the service.

We considered as services all the benefits that were offered by the ecosystem, both in its biotic and abiotic components. We discarded: a) benefits obtained from human infrastructure, such as paved roads and public lighting, b) conditions that favor the achievement of benefits, such as government support, c) management practices for these benefits, such as the hauling of water for livestock, and d) structure of the ecosystem, such as the shape of the land or the space available to develop or extend productive activities.

To classify each service into a type according to the nomenclature proposed by the Millennium Ecosystem Assessment (MEA 2005), we used the following definitions: a) Provisioning: services that interact directly with individuals for the satisfaction of basic needs, such as food, health, room, b) Regulating: services that interact indirectly with individuals through the regulation of the biophysical conditions of the socio-ecosystem to promote their direct well-being or to regulate of agricultural activities, c) Cultural: tangible or intangible benefits that arise from experiences or capacities of the interactions between individuals and their environment, and d) Supporting: basic ecosystem processes that support the offer of other services.

\section{2- Development of the Importance Value Index}

In the laboratory, we digitized the flipchart obtained from each interview. From each flipchart, we extracted two details of the services represented on the cards: 1) the position of each card (from its center) over the horizontal gradient (from 0 to 1) using Data Thief software (http://datathief.org/), and 2) the order of importance expressed by the interviewee from the order in which it was selected (in decreasing order).

With these data, we constructed an Importance Value index related to each service, per cattle rancher (Individual Importance Value). The Individual Importance Value (equation 3.1) was obtained by multiplying the value of the " $p$ " position of the service " $i$ " on the horizontal gradient by the second term of the equation. The second term was obtained by subtracting the ratio of the order in which $(o)$ the service " $i$ " appeared and the total of services $(N)$ recognized by the cattle rancher " $j$ " from the maximum value found (1) among the " $i$ " services.

$$
\text { Importance value }=p_{i} \times\left[1-\left(\frac{o}{N_{j}}\right)\right]
$$


In addition, we obtained two indicators of the importance of each service from the group of cattle ranchers. The General Importance Value was based on Individual Importance Value and resulted from the addition of the Individual Importance Value attributed to each service by the individual cattle ranchers who mentioned it. The general frequency resulted from the number of mentions given to each service. 
Appendix 4. Cattle ranchers' livelihoods: analysis and results

We analyzed the cattle rancher's livelihoods according to their socio-demographic variables (see Appendix 2). We used a Multiple Correspondence Analysis (MCA) when individuals were described by categorical variables (Le et al. 2008). MCA allowed us to see the relationship between variables and the associations between categories, and to characterize groups of individuals by category studied.

MCA also permitted us to explore patterns within a set of categorical variables. The ordering was composed of the dimensions which are obtained from the categorical variables. MCA was then used to graphically summarize relationships among different categories and as pre-processing before doing a Hierarchical Clustering on Principal Components (HCPC) analysis. HCPC was used to graphically summarize relationships among different individuals and their livelihoods.

Results showed that the variables, education, diversity of productive activity, and age; describe the dimension 1 of the principal components (Fig. A4.1). Other variables (e.g "ejidatarios") are linked to both first and second dimensions. A deep knowledge of (levels) categories allowed us to interpret these relationships (Table A4.1).

Fig. A4.1. Representation of the categories according to the dimensions of MCA. Education ("escolaridad_f"), age ("edad_f") and diversity of productive activity ("otra_act_f") are linked to dimension 1 (which explains the $19.39 \%$ variation between individuals).

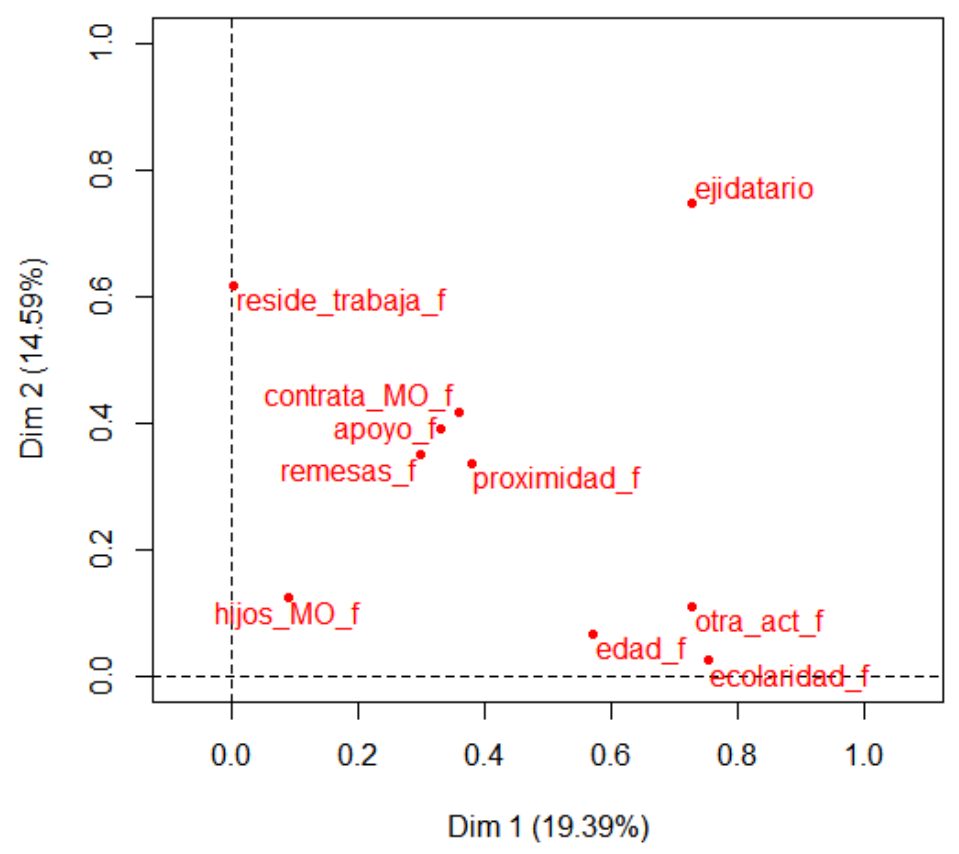


Table A4.1. Description of the dimension 1 by level of categorical variables: Education ("escolaridad_f") = None-incomplete means that the cattle rancher had not attended school or only studied a few years at primary school. Productive activity ("otra_act_f") = the cattle rancher had no another productive activity apart from cattle raising. Age ("edad_f") = was older than 65 years old.

\begin{tabular}{llll}
\hline Variable & Category & $\begin{array}{l}\text { Estimated value (in } \\
\text { test.t) }\end{array}$ & p-value \\
\hline Education & None-incomplete & 0.568 & $4.888985 \mathrm{e}-09$ \\
Productive activity & No (has another activity) & 0.558 & $1.588251 \mathrm{e}-08$ \\
Age & Older & 0.495 & $5.099098 \mathrm{e}-06$ \\
\hline
\end{tabular}

We found two subgroups between individual cattle ranchers in a hierarchical clustering (Fig. A4.2). Members of subgroup 1 (cluster 1, in black) were characterized by the highest education and diversity of productive activities and, in general, were younger than 65 years old. Members of subgroup 2 (cluster 2, in red) were characterized by less education and diversity of productive activity, and, generally were older than 65 years.

Fig. A4.2. Factorial map showing the two subgroups of individuals suggested by the HCPC analysis on the principal component map. Cluster 1 is described as subgroup 1 and cluster 2 is subgroup 2 .

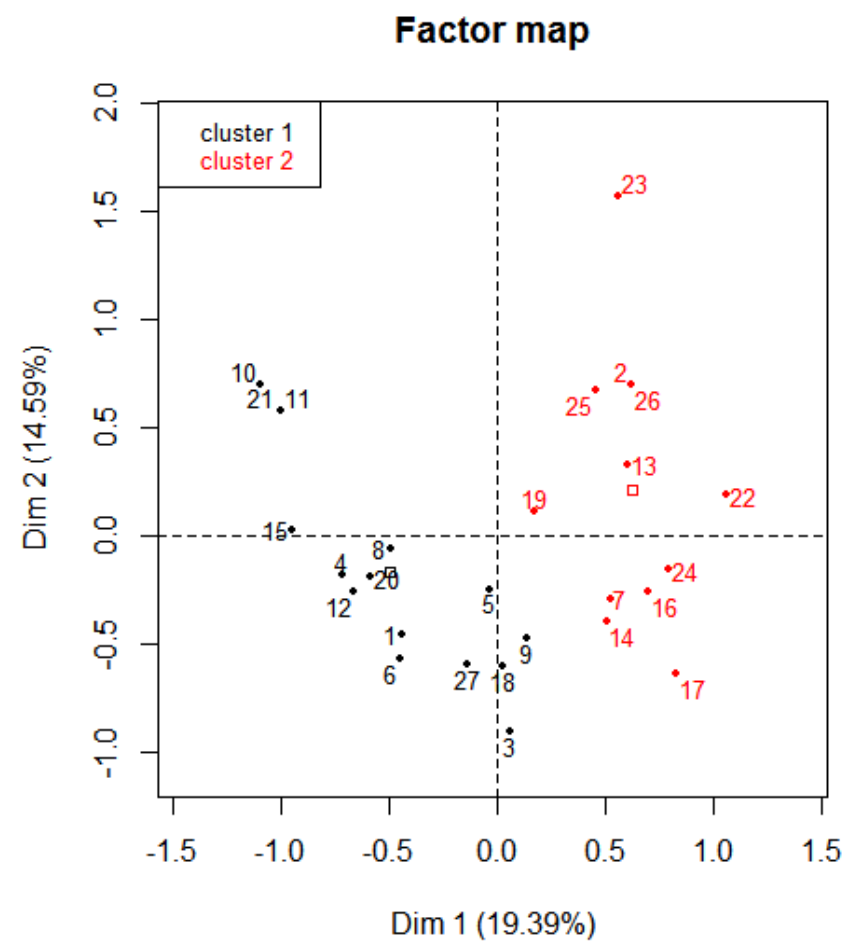



Appendix 5. Ecosystem services importance and relationships

5.1- Ecosystem services and Importance Value index

We showed the ecosystem services perceived according to how their importance was ranked by cattle ranchers (Table A5.1).

Table A5.1. The 54 ecosystem services defined according to the benefits perceived by cattle ranchers. Services were ordered according to the General Importance Value (the value of added importance for each service by the total of cattle ranchers) and the General Frequency (the number of mentions).

\begin{tabular}{llll}
\hline \hline $\mathrm{N}^{\mathbf{o}}$ & Ecosystem service & $\begin{array}{l}\text { General Importance } \\
\text { Value }\end{array}$ & $\begin{array}{l}\text { General } \\
\text { Frequency }\end{array}$ \\
\hline 1 & Pasture for livestock & 12.87 & 26 \\
2 & Water for livestock & 10.76 & 22 \\
3 & Rain & 10.51 & 16 \\
4 & Food derived from maize & 9.97 & 19 \\
5 & Aesthetic appreciation of nature and the & 9.33 & 21 \\
& landscape & 9.10 & \\
6 & Cultivated fodder & 6.46 & 19 \\
7 & Forest-rain interactions & 5.76 & 10 \\
8 & Habitat & 5.20 & 12 \\
9 & Protection of nature & 4.95 & 9 \\
10 & Wood & 4.76 & 16 \\
11 & Air quality & 4.50 & 8 \\
12 & Water for life (wild) & 4.28 & 10 \\
13 & Life & 4.26 & 7 \\
14 & Food derived from fishing & 4.24 & 11 \\
15 & Shade for livestock & 3.97 & 17 \\
16 & Coolness & 3.92 & 9 \\
17 & Water usage for humans & 3.42 & 8 \\
18 & Regulating the flow of water & 3.18 & 6 \\
19 & Aesthetic appreciation of wildlife & 3.02 & 9 \\
20 & Potential aesthetic appreciation for others & 2.94 & 11 \\
21 & Soil protection & 6 \\
22 & Aesthetic appreciation of the landscape for & 2.87 & 8 \\
& oneself & & \\
23 & Grazing from the forest & 2.75 & 12 \\
24 & Aural appreciation of the fauna & 2.55 & 5 \\
25 & Post & 2.49 &
\end{tabular}


26 Soil moisture and the vegetation $\quad 2.48$

27 Interactions and properties of the ecosystem

28 Recreational activities in nature

29 Food derived from wild plants or animals

30 Food derived from ranching

31 Appreciation of the positive qualities of productive environments

32 Multiples use for wild species $\quad 1.70$

$1.70 \quad 6$

33 Recharging of groundwater

34 Fire wood

35 Recreational activities in bodies of water and the ocean

36 Soil fertility

0.96

37 Environmental

0.78 conditions for wild plants

38 Water for irrigation

0.73

39 Regulating water quality

0.71

40 Control of pests

0.65

41 Carbon capture

0.64

42 Fallen leaves and fertilizer in the soil

0.58

43 Food for other domestic animals

0.49

44 Future knowledge of animal life

0.40

45 Productivity

0.40

46 Aural appreciation of water

0.39

47 Seasonality (dry)

0.39

48 Perches for birds

0.34

49 Food for wildlife

0.30

50 Health

0.27

51 Rock

0.25

52 Dairy cattle

0.13

53 Happiness

0.12

$54 \quad$ Spirituality

0.02

\section{2- Ecosystem services relationships}

Quotes supporting the relationship among ecosystems services, as explained by the perception of five cattle ranchers $(\mathrm{CR})$. 
1) "Grazing from the forest" and tree canopy or forest vegetation link:

"[the forest vegetation is a benefit] because we need everything that we have, for ourselves and for animals. (...) For example, as in the photo, you can walk here, all this and then any "matita" (plant) can eat the cattle" (CR6).

2) Services derived from crops (eg. "Food derived from maize", "Cultivated fodder") are supporting in the "soil fertility":

"Well, this terrain is suitable to you want to cultivate. Here all grow, (for example) jitomate, tomato. Look! all soil of here in the coastal zone is dry, in-plane terrain, all you cultivated and irrigated (from different water source "agua rodadiza, agua de pozo o arroyo"), is securely cultivated because here all growing. (...) Here you don't need fertilizers like the "grain" or "sulfate". Here the terrain has it. This high-quality of "milpa" (maize crop) that we see here, we don't add nothing to it" (CR19).

3) Productivity and fertility link

"The green, when the land is fertile there are beautiful plants; is like when you feed one to the children and if you do not feed them, they are hungry, they are sleep, yes or no?" (CR5).

4) Primary productivity and seasonality of tropical dry forest link:

"The benefit of seeing all that mountain as it is, are the rains. It is the benefit of being so, is beautiful, is green" (CR18).

5) Decomposition and soil fertility linked to seasonality:

"But there are no green trees here. It is dry. It is not dry! it is leafless, it has no foliage!. (...) Here the benefit is in the land that is generating fertilizer for the trees because the fallen leaf is disrupted and is giving benefit to the trees because it is as if it were fuel (...). Yes, the rain arrives, it gets pretty green and also the trees are taking advantage. (...) the leaf litter helps to fertilize and even if the top is without leaves. They are the leaves, which fall to the ground and generate nutrients for the trees" (CR13). 
Appendix 6. Reasons of importance that sustain the ecosystem services prioritized

Table A6.1. Each textual quote (A-X) corresponds to an ecosystem service prioritized by each cattle rancher (CR); see Table 2 for the quotes in gray here. The reasons of importance are codified in three large categories (Figure 4). Each reason of importance is discussed and the context that supports the interpretation of the categories which emerged from these reasons is given.

\begin{tabular}{|c|c|c|c|}
\hline Quote & $\begin{array}{l}\text { Ecosystem } \\
\text { service }\end{array}$ & Reasons of importance & Commentary and context \\
\hline $\mathrm{A}$ & $\begin{array}{l}\text { Pasture for } \\
\text { livestock }\end{array}$ & $\begin{array}{l}\text { "For me this is life, the cattle " } \\
\text { CR22 }\end{array}$ & $\begin{array}{l}\text { Benefit for developing as a } \\
\text { producer. He obtains his } \\
\text { economic support from } \\
\text { ranching work. }\end{array}$ \\
\hline B & $\begin{array}{l}\text { Pasture for } \\
\text { livestock }\end{array}$ & $\begin{array}{l}\text { "For the livestock, because } \\
\text { without the cattle there is } \\
\text { nothing." CR23 }\end{array}$ & Idem quote $\mathrm{A}$ \\
\hline $\mathrm{C}$ & $\begin{array}{l}\text { Pasture for } \\
\text { livestock }\end{array}$ & $\begin{array}{l}\text { "There [in the pasture] the } \\
\text { farmer has the benefit }(. . .) \text { " } \\
\text { CR7 }\end{array}$ & Idem quote $\mathrm{A}$ \\
\hline $\mathrm{D}$ & $\begin{array}{l}\text { Pasture for } \\
\text { livestock }\end{array}$ & $\begin{array}{l}\text { "I am eating from my animals, } \\
\text { from there I help myself" CR2 } 6\end{array}$ & Idem quote $\mathrm{A}$ \\
\hline $\mathrm{E}$ & $\begin{array}{l}\text { Rain - Water } \\
\text { for livestock }\end{array}$ & $\begin{array}{l}\text { The rain and the water } \\
\text { (provided for the livestock) } \\
\text { permit him to sustain his } \\
\text { ranching activity (...) CR20 }\end{array}$ & $\begin{array}{l}\text { Rain in is first linked to water } \\
\text { for the livestock, which } \\
\text { supports ranching activity as } \\
\text { work and livelihood [see } \\
\text { relation to well-being, quote } \\
\text { L]. }\end{array}$ \\
\hline $\mathrm{F}$ & $\begin{array}{l}\text { Pasture for } \\
\text { livestock }\end{array}$ & $\begin{array}{l}\text { (...) "but to have it nice you } \\
\text { have to work it nicely, if not it } \\
\text { becomes overgrown and the } \\
\text { grass finishes" CR7 }\end{array}$ & $\begin{array}{l}\text { The work implies different } \\
\text { practices, so that the } \\
\text { secondary forest does not } \\
\text { regenerate (does not } \\
\text { "enmonte"). These practices } \\
\text { can lead to the use of fire (to } \\
\text { burn) or a machete (to clear). }\end{array}$ \\
\hline G & Rain & $\begin{array}{l}\text { Brings water and helps the } \\
\text { ranching activity. CR1 }\end{array}$ & $\begin{array}{l}\text { The rain fills the bodies of } \\
\text { water. A management } \\
\text { practice involves moving } \\
\text { ("carry") the water to the } \\
\text { troughs of the paddock. }\end{array}$ \\
\hline $\mathrm{H}$ & Rain & $\begin{array}{l}\text { "with good rain, there is a } \\
\text { harvest and you can raise the } \\
\text { cattle" CR4 }\end{array}$ & $\begin{array}{l}\text { The maize crop that is } \\
\text { seasonally produced provides } \\
\text { fodder for the livestock. A }\end{array}$ \\
\hline
\end{tabular}




I Rain when the rain falls (and) it
benefits us because the trees,
when there is a plantation, then
(...) [water themselves without
the necessity of doing it
oneself]" CR5

J Pasture for livestock

K Rain

L Rain - Water

for livestock

M

Pasture for livestock

$\mathrm{N}$ this activity is related to other benefits in search of a "better quality of life" CR20

"I get sad if I sell one (a livestock animal). I am proud that my animals are happy... and I believe that they are also happy [in addition from the same cattle rancher]" R26

"The rain, the grazing, with the rain there is grass and happy cows" CR21

"I get sad if I sell one (a livestock animal). I am proud that my animals are happy (...)" CR26

"I would like to see this environment [the forest], but to do this [the forest, the trees, the river] have to have this [rain]" CR27 common practice is to take advantage of the stubble that is mixed with other products to make balanced nourishment for the livestock or to store for the dry season.

In a plantation of fruit trees, watering by the rain is beneficial instead of watering with buckets, a physically taxing practice. The fruit plantation was viewed as an activity complementary to ranching.

He relates grazing with the well-being of the livestock expressed as the happiness of the livestock. In addition, he observes a link between the happiness of the animals and his own [see quote $\mathrm{M}$ ].

The well-being of the livestock is supported by the productive trio. Well-being is expressed as the cows' happiness.

[comes from quote E] to have a "better quality of life" is associated with material wellbeing. For example, "a better quality" refers to having enough money to gain access to different good and products.

Expression of emotion, sentiment toward his animals that relates to their own subjective well-being [comes from quote J].

Subjective well-being expressed as a desire for liking, enjoying, "seeing" the forest sustained by the rain [see quote U]. 


\begin{tabular}{|c|c|c|c|}
\hline $\mathrm{O}$ & $\begin{array}{l}\text { "Rain and } \\
\text { recharging } \\
\text { groundwater } \\
\text { along with } \\
\text { other } \\
\text { services" }\end{array}$ & $\begin{array}{l}\text { "the importance of [services } \\
\text { offered by forestry } \\
\text { conservation] lies in the fact } \\
\text { that it provides benefits for } \\
\text { humanity... those [individuals] } \\
\text { with or without cattle, and } \\
\text { whether or not they are farmers, } \\
\text { as we all need it, to survive as } \\
\text { humans; thus we need frequent } \\
\text { rain so that we will have } \\
\text { resources for subsequent } \\
\text { generations. I may die at any } \\
\text { time, but my children also need } \\
\text { it. If we continue to cut down } \\
\text { trees, we will end this beauty" } \\
\text { CR15 }\end{array}$ & $\begin{array}{l}\text { The services offered in the } \\
\text { preserved forest are sustained } \\
\text { by the rain. The priority for } \\
\text { the package in which all } \\
\text { services are perceived as } \\
\text { interrelated was an expression } \\
\text { of support for the collective } \\
\text { human well-being. } \\
\text { Importance is also attributed } \\
\text { to maintaining the services for } \\
\text { future generations. }\end{array}$ \\
\hline $\mathrm{O}^{*}$ & $\begin{array}{l}\text { Forest-rain } \\
\text { interactions }\end{array}$ & $\begin{array}{l}\text { "the vegetation calls the water, } \\
\text { the rain, that is beneficial for } \\
\text { everything, the streams grab the } \\
\text { water, it is for all types of } \\
\text { animals, for one. Water wells } \\
\text { and everything and there runs } \\
\text { the water for Nacastillo, } \\
\text { Ranchito, Juan Gil" CR16 }\end{array}$ & $\begin{array}{l}\text { This service upheld its } \\
\text { importance in the collective } \\
\text { well-being. The interaction of } \\
\text { the vegetation with the rain } \\
\text { supports the life of many } \\
\text { animal species and humans in } \\
\text { the community. He refers to } \\
\text { the water that collects on a hill } \\
\text { as headwaters; these provide } \\
\text { water for three of the studied } \\
\text { ejidos. }\end{array}$ \\
\hline $\mathrm{P}$ & $\begin{array}{l}\text { Water for } \\
\text { livestock }\end{array}$ & $\begin{array}{l}\text { "A paddock without water, no, } \\
\text { doesn't work at all, and with } \\
\text { water, yes. With no water, there } \\
\text { is no pasture (...) the two are } \\
\text { important [pasture and water]" } \\
\text { CR9 }\end{array}$ & $\begin{array}{l}\text { The grassland depends on } \\
\text { water. Both are required for } \\
\text { ranching production. A } \\
\text { water-pasture-livestock triad } \\
\text { is established. }\end{array}$ \\
\hline Q & $\begin{array}{l}\text { Water for } \\
\text { livestock }\end{array}$ & $\begin{array}{l}\text { "Here there is grassland but no } \\
\text { water, there isn't anything. If } \\
\text { there is water, the pasture can } \\
\text { water itself" CR } 17\end{array}$ & Idem quote $\mathrm{P}$ \\
\hline $\mathrm{R}$ & Rain & $\begin{array}{l}\text { "There is pasture and water for } \\
\text { the animals, there is vegetation. } \\
\text { (...) The same rain produces } \\
\text { this [the pasture, the } \\
\text { vegetation]" CR6 }\end{array}$ & $\begin{array}{l}\text { The quote explains the rain as } \\
\text { the origin of water for the } \\
\text { livestock, the pasture and the } \\
\text { vegetation in general. A } \\
\text { productive triad supported by } \\
\text { the rain is established. }\end{array}$ \\
\hline
\end{tabular}




\begin{tabular}{|c|c|c|c|}
\hline$S$ & Rain & $\begin{array}{l}\text { "First of all (this) is the rain, } \\
\text { because without rain then there } \\
\text { is no [harvest, grassland, } \\
\text { water]" CR13 }\end{array}$ & Idem quote R. \\
\hline $\mathrm{T}$ & Rain & $\begin{array}{l}\text { (...) "also [rain is beneficial] for } \\
\text { the trees of the countryside. } \\
\text { Rain falls and they start to turn } \\
\text { green" CR5 }\end{array}$ & $\begin{array}{l}\text { Rain relates to productivity } \\
\text { and to different processes of } \\
\text { the ecosystem. }\end{array}$ \\
\hline $\mathrm{U}$ & Rain & $\begin{array}{l}\text { "I would like to see this } \\
\text { environment [the forest], but to } \\
\text { achieve this [the forest, the } \\
\text { trees, the river] must have this } \\
\text { [the rain]" CR27 }\end{array}$ & $\begin{array}{l}\text { [from quote } \mathrm{N} \text { ] A causal } \\
\text { relationship is expressed } \\
\text { between the enjoyment of } \\
\text { seeing the forest and the } \\
\text { ecosystem relationships that } \\
\text { are supported in the rain. }\end{array}$ \\
\hline V & Rain & $\begin{array}{l}\text { "is that it gives us life...to the } \\
\text { cattle and to us also" CR14 }\end{array}$ & In an existential sense. \\
\hline $\mathrm{W}$ & Rain & $\begin{array}{l}\text { "without rain there might not } \\
\text { be anything" CR18 }\end{array}$ & In an existential sense. \\
\hline $\mathrm{X}$ & Rain & $\begin{array}{l}\text { "without water no one can live" } \\
\text { CR24 }\end{array}$ & In an existential sense. \\
\hline
\end{tabular}

Table A6.2. The reasons associated with the importance attributed to prioritized services according to members of cattle ranchers subgroup. Subgroup 1: highest education and diversity of productive activities. Subgroup 2: little or no education level and only cattle ranchers.

\begin{tabular}{llll}
\hline Reasons of importance & Ecosystem services prioritized & $\begin{array}{l}\text { Cattle } \\
\text { rancher } \\
\text { subgroup } \\
1(*)\end{array}$ & $\begin{array}{l}\text { Cattle } \\
\text { rancher } \\
\text { subgroup } \\
2(*)\end{array}$ \\
\hline Cattle well-being & Rain & 1 & 1 \\
Material well-being & Pasture for livestock & 1 & 1 \\
& Rain & 1 & 1 \\
& Water usage for humans & & \\
Social well-being & $\begin{array}{l}\text { Food derived from maize } \\
\text { "Rain + rain and recharging } \\
\text { groundwater along with other } \\
\text { services" }\end{array}$ & 1 &
\end{tabular}


Forest-rain interaction

Subjective well-being

Existence

Ecosystem interrelations

Economic support

Management practice

Productive "triad"
Rain

Pasture for livestock

"Appreciation and recreation"

Aesthetic appreciation of the landscape for oneself

Rain

Forest-rain interaction

Rain

"Habitat + rain + appreciation"

Recharging of groundwater

Rain

Pasture for livestock

Rain

Pasture for livestock

Recharging of groundwater

Rain

Water for livestock
1

1

1

1

1

2

1

2

1

1

3

\section{1}

1

1

1

(*) the priority of a cattle rancher for an ecosystem service can be codified under different importance reasons. For example, see E, L, quotes from CR20 in Table 2, where the interpretation of the importance of rain for the cattle rancher lies both in the economic support and material well-being rain offers. 